F.

FFR 231850

OSTI

Hybrid Energy Storage Test Procedures and High Power Battery Project FY-1995 Interim Report

G. L. Hunt Engineering Laboratory 


\section{DISCLAIMER}

This report was prepared as an account of work sponsored by an agency of the United States Government. Neither the United States Government nor any agency thereof, nor any of their employees, makes any warranty, express or implied, or assumes any legal liability or responsibility for the accuracy, completeness, or usefulness of any information, apparatus, product or process disclosed, or represents that its use would not infringe privately owned rights. References herein to any specific commercial product, process, or sevice by trade name, trademark, manufacturer, or otherwise, does not necessarily constitute or imply its endorsement, recommendation, or favoring by the United States Government or any agency thereof. The views and opinions of authors expressed herein do not necessarily state or reflect those of the United States Government or any agency thereof. 
INEL-95/0542

\title{
Hybrid Energy Storage Test Procedures and \\ High Power Battery Project
}

\section{FY-1995 Interim Report}

\section{December 1995}

\author{
G. L. Hunt
}

\section{DISCLAIMER}

This report was prepared as an account of work sponsored by an agency of the United States Government. Neither the United States Government nor any agency thereof, nor any of their employees, makes any warranty, express or implied, or assumes any legal liability or responsibility for the accuracy, completeness, or usefulness of any information, apparatus, product, or process disclosed, or represents that its use would not infringe privately owned rights. Reference herein to any specific commercial product, process, or service by trade name, trademark, manufacturer, or otherwise does not necessarily constitute or imply its endorsement, recommendation, or favoring by the United States Government or any agency thereof. The views and opinions of authors expressed herein do not necessarily state or reflect those of the United States Government or any agency thereof. 


\section{Contents}

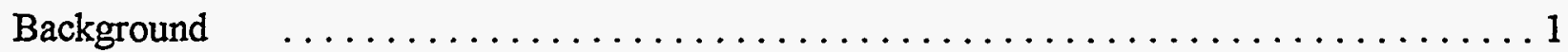

Summary of FY-1995 Activities . . . . . . . . . . . . . . . . . . . . . . . . . . . 1

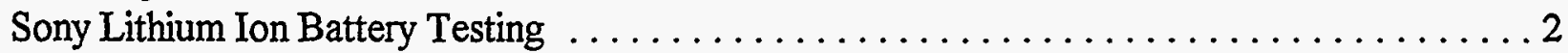

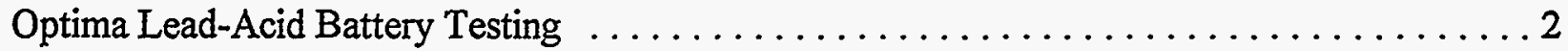

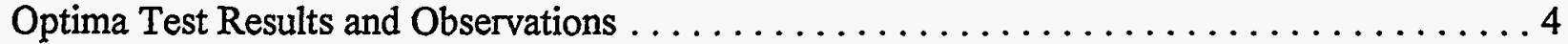

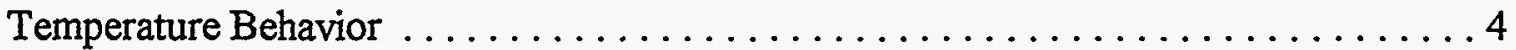

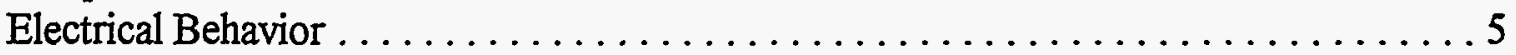

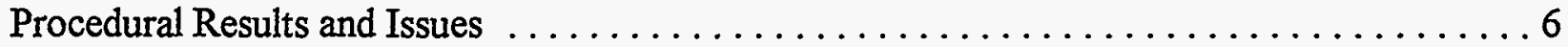

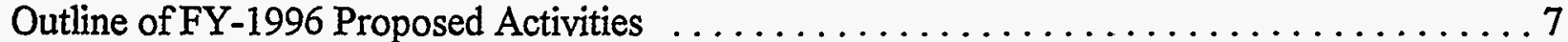

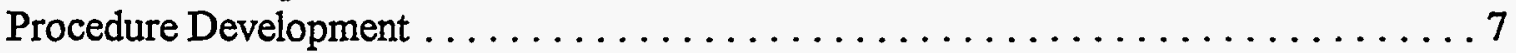

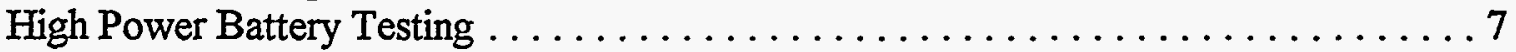

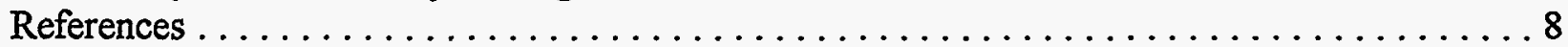

\section{Tables}

1. Summary Test Results for Sony NP-500H Lithium Ion Cells $\ldots \ldots \ldots \ldots \ldots$

2. Summary Test Results for Optima Battery Modules .................. 9 


\section{Figures}

1. Sony Lithium Ion Peak Power Current and Voltage $\ldots \ldots \ldots \ldots \ldots \ldots \ldots \ldots$

2. Sony Lithium Ion Peak Power OCV and Resistance $\ldots \ldots \ldots \ldots \ldots \ldots \ldots \ldots \ldots$

3. Sony Lithium Ion Peak Power Capability $\ldots \ldots \ldots \ldots \ldots \ldots \ldots \ldots \ldots \ldots$

4. Optima Module 3 Peak Power Current and Voltage . . . . . . . . . . . . . . . . . . 14

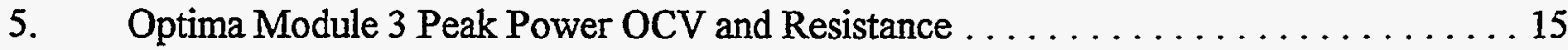

6. Optima Module 3 Peak Power Capability . . . . . . . . . . . . . . . . . . . . . . 16

7. Optima Module 1 Peak Power Current and Voltage . . . . . . . . . . . . . . . 17

8. Optima Module 1 Peak Power OCV and Resistance . . . . . . . . . . . . . . . 18

9. Optima Module 1 Peak Power Capability . . . . . . . . . . . . . . . . . . . . . . 19

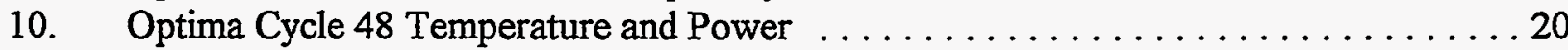

11. Optima Cycle 49 Temperature and Power ................... 21

12. Optima Cycle 50 Temperature and Power ................... 22

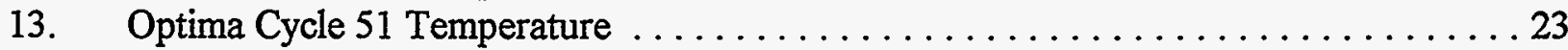

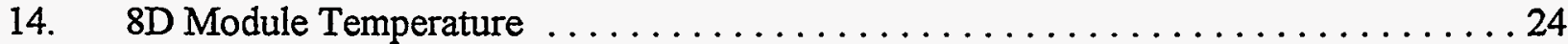

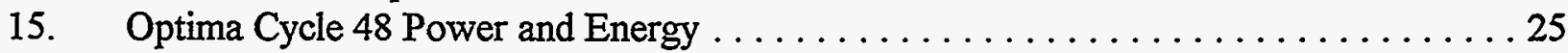

16. Optima Cycle 49 Power and Energy . . . . . . . . . . . . . . . . . . 26

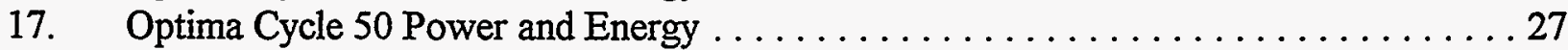

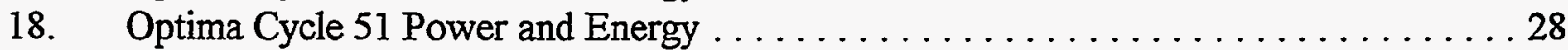

19. $8 \mathrm{D}$ Module Power and Energy ... . . . . . . . . . . . . . . . . . . . . . . 29

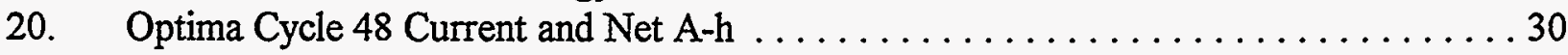

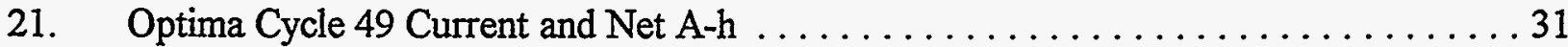

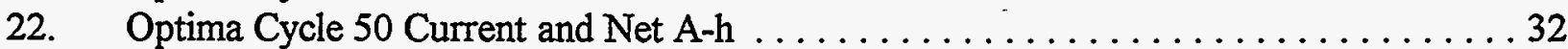

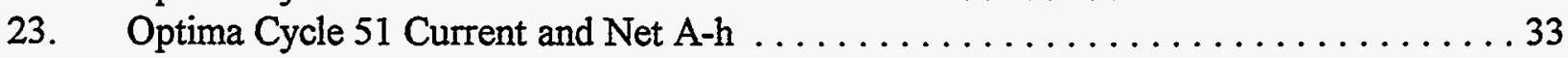

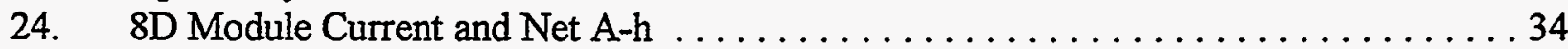

25. Optima Cycle 50 Net A-h and Energy (full test) $\ldots \ldots \ldots \ldots \ldots \ldots \ldots \ldots \ldots$

26. $8 \mathrm{D}$ Module Net A-h and Energy (full test) $\ldots \ldots \ldots \ldots \ldots \ldots \ldots \ldots \ldots \ldots \ldots$

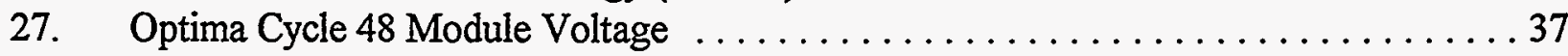

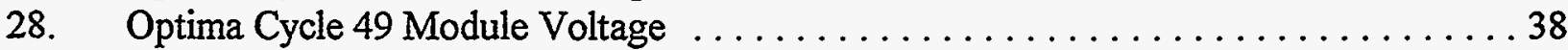

29. Optima Cycle 50 Module Voltage . . . . . . . . . . . . . . . . . . . . . . 39

30. Optima Cycle 51 Module Voltage . . . . . . . . . . . . . . . . . . . . 40

31. $8 \mathrm{D}$ Module Voltage $\ldots \ldots \ldots \ldots \ldots \ldots \ldots \ldots \ldots \ldots \ldots \ldots \ldots \ldots \ldots \ldots$ 


\section{Background}

Near the end of FY-1994, DOE provided funding and guidance to INEL for two separate but closely related tasks involving high power energy storage technology. One task was intended to develop and refine application-specific test procedures appropriate to high power energy storage devices for potential use in hybrid vehicles, including batteries, ultracapacitors, flywheels, and similar devices. The second task was intended to characterize the high power capabilities of presently available battery technologies, as well as eventually to evaluate the potential high power capabilities of advanced battery technologies such as those being developed by the USABC. Since the evaluation of such technologies is necessarily dependent to some extent on the availability of appropriate test methods, these two tasks have been closely coordinated. This report is intended to summarize the activities and results for both tasks accomplished during FY1995.

\section{Summary of FY-1995 Activities}

During the first quarter of FY-1995, significant effort was devoted to defining the performance and life requirements for hybrid energy storage devices, based primarily on discussions with and information obtained from DOE and auto company personnel involved in establishing such requirements. A composite set of requirements were tabulated, based on the best available information, for hybrid vehicles operating in either dual mode (where a vehicle might be required to operate entirely from stored electrical energy in some conditions) or power assist mode (where stored electrical energy is used only to supplement some other power source.) From these requirements, candidate test cycles were considered for incorporation into one or more hybrid test regimes. These candidate tests were studied both for their likely relationship to actual vehicle behavior (based on some limited simulation modeling) and some practical testing considerations. This effort was summarized in a letter report (unpublished) provided to DOE for review in December 1994. As a follow-on, a conference paper (Reference 1) was prepared for the 1995 IECEC meeting in cooperation with DOE Headquarters personnel. This paper summarized this effort and gave somewhat greater emphasis to the practical problems expected for such testing. An approximation to the proposed test cycle was subsequently programmed for one of the INEL battery testers and used for the Optima testing described later.

Also early in FY-1995, a number of Sony lithium ion cells were obtained and subjected to a series of characterization tests to determine their suitability for use as high power devices. This work was reported in an (unpublished) interim test report delivered to DOE in April 1995, and the results are repeated in this report. Some Optima lead-acid battery modules were also purchased on the basis of claimed high power capability and subjected to characterization testing. Results of this testing have not previously been reported but are covered in this report.

In the summer of 1995 , a draft procedure was prepared for module-level testing using a Bitrode tester and added to the INEL battery test procedures manual. This procedure was then used for a short series of tests on two different battery modules, with results as described in detail in a later section of this report. 


\section{Sony Lithium Ion Battery Testing}

A total of 12 Sony lithium ion cells (Model NP-500H) were purchased over a period of several months. These cells were all contained in off-the-shelf camcorder battery packs purchased from local suppliers, which were then disassembled to allow the cells to be tested individually. Sony intends these batteries to be recharged with a commercially available charger using proprietary algorithms. This charger could not be used with individual cells, so the best available information on how to charge the cells was acquired from outside sources (primarily Lawrence Livermore, where similar cells were tested for space applications.)

The first cells purchased were subjected to characterization using standard USABC test procedures for constant current testing, constant power testing and peak power capability testing. This approach was taken for two reasons: an actual high power test procedure had not yet been drafted until several months after the cells were received, and it seemed prudent to establish baseline performance on standard tests before subjecting these cells to an untried and very demanding high power test procedure. The results of this testing are summarized in Table 1, and the results of subjecting cell number 1 to the USABC Peak Power test procedure are illustrated graphically in Figures 1 through 3. Only 3 of the 12 cells purchased achieved their rated capacity. One was failed (shorted) on arrival, and 8 others were subjected only to 3-hour capacity tests. Additionally, the first cell subjected to peak power testing showed a loss of about 9 percent of its measured capacity afterward. Before this behavior could be investigated further, all INEL cell test stations were diverted to high priority USABC testing activities, and this testing has not yet been resumed. Twelve additional cells have been purchased in the interim for future use.

\section{Optima Lead-Acid Battery Testing}

Three 12 volt sealed lead-acid battery modules made by Optima were acquired in mid-FY95. These batteries are constructed with spiral-wound electrodes intended to provide very high power capability. They are rated for a maximum current of 725A for up to 30 seconds, with a maximum charge current of 300A. One of the modules was leaking on arrival and was not tested. The other two were subjected to USABC constant current, constant power, variable power (DST) and peak power capability tests, for the same reasons explained above for the Sony cells. The results of this testing are summarized in Table 2. The peak power tests performed originally were not terminated in accordance with the standard USABC procedure, so that peak power at DODs above $70 \%$ was not determined. (See Figures 4 through 6 for sample results.) The peak power test was repeated on module 1 (as Cycle 52) after the high power testing described below, and the results are shown in Figures 7 through 9. For comparison with later results, it should be noted that the modules were capable of producing about $250 \mathrm{~W} / \mathrm{kg}$ or more down to about $50 \% \mathrm{DOD}$; by $80 \%$ DOD this had declined to about $80 \mathrm{~W} / \mathrm{kg}$.

A high power test procedure based on the Reference 1 recommendations was constructed based on programming capabilities of the INEL Bitrode tester which was used for characterization testing. This tester is intended for module testing up to 20 volts. It has a maximum discharge current capability of 500A and a maximum charge/regen current capability of $150 \mathrm{~A}$; these limits consequently also constrain the maximum charge and discharge powers which are available using this tester. 


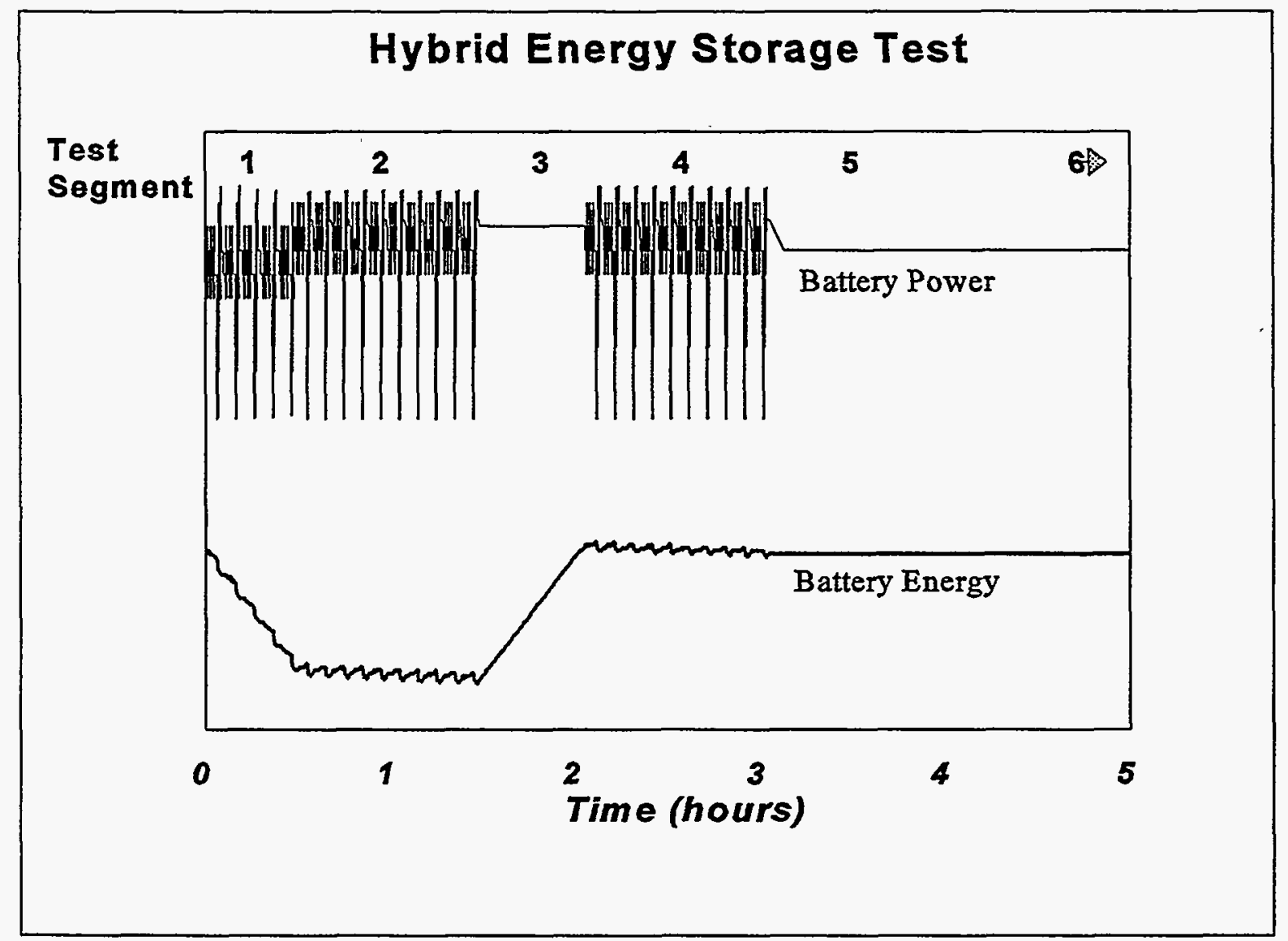

The test procedure contained six "segments" in the following sequence, as illustrated in the diagram above:

\section{Segment Description}

1.

Normal DST profiles scaled to about $300 \mathrm{~W} / \mathrm{kg}$ peak (for the Optima $21 \mathrm{~kg}$ modules), repeated until a fixed number of ampere-hours (35 in this case) are removed from the battery

2. Shifted DST profiles with the same relative amplitude as segment 1 , but offset such that the nominal energy removed by one profile is zero, and repeated for a fixed time interval (one hour in this case)

3. Constant power recharge at the same average power as segment 1 , for a fixed number of ampere-hours ( 25 in this case)

4. Repeat of segment 2 (shifted DSTs for one hour) [at a higher state of charge than segment 2, obviously]

5. Rest period for battery temperature to return to normal operating region

6. Normal recharge to return battery to full charge (for the Optima battery, this is a $4 \mathrm{~A}$ constant current to $15 \mathrm{~V}$, followed by $15 \mathrm{~V}$ constant voltage for 2 hours)

During the DST segments $(1,2$ and 4$)$, the maximum and minimum voltages for the module were limited (clamped) to 14.5 and 10.5 volts respectively.

Before subjecting the Optima modules to this test procedure, two iterations of the procedure were performed on a large utility lead-acid battery module, designated $8 \mathrm{D}$ (which is its package size.) 
This module, which is several times the size of the Optima modules, is not assigned an INEL identification number because it is used only for checkout of equipment and test setups, and results from its use are not normally reported. The first test conducted with this module disclosed two errors in the test program which were corrected before proceeding. The second test was successful, and the results are shown graphically in accompanying figures. This information is included for comparison to the Optima results which were subsequently obtained using the identical test program (scaled to the identical power values), because the differences help to illustrate some of the procedural concerns discussed in the next section.

Four iterations of this test procedure were performed on Optima module No. 1 as discharge cycles $48,49,50$ and 51 . The test program was identical for all four tests; test conditions differed only with respect to the control of battery temperature, as follows:

- Cycle 48 was performed with the battery at laboratory ambient temperature with a fan blowing some air over it

- Cycle 49 was performed with the battery in a temperature chamber set at about $25^{\circ} \mathrm{C}$, with the chamber temperature controlled by a thermocouple mounted on the battery module (i.e. the chamber tried to maintain constant battery temperature during the test)

- Cycle 50 was performed with the battery in a temperature chamber set at about $25^{\circ} \mathrm{C}$, with chamber control based on chamber temperature

- Cycle 51 was identical to Cycle 49, except that the chamber air temperature was recorded

The results of these tests are shown by several groups of graphs (distinguished by discharge cycle number) accompanying this report. Most of these results are shown only for the first 3 to 4 hours of each test, which includes segments 1-4 and the beginning of segment 5 . The total test interval of 10 hours or more is shown only in selected cases.

\section{Optima Test Results and Observations}

\section{Temperature Behavior}

Module temperature in Cycle 48 (free air test) [Figure 10] rose steadily through the test and peaked at about $48^{\circ} \mathrm{C}$ at the end of segment 4 . This caused some concern because ambient temperature batteries under test in the INEL battery lab are also monitored by a safety shutdown system which is normally set at $50^{\circ} \mathrm{C}$ to prevent damage due to battery thermal runaway or fire; if the battery temperature had exceeded $50^{\circ} \mathrm{C}$, other test stations in the lab might have been shut down as well. Additionally, the cooldown to ambient temperature took several hours, which delayed completion of the final recharge. By comparison, the $8 \mathrm{D}$ module [Figure 14] only reached $33^{\circ} \mathrm{C}$, although it took even longer to cool down; this difference is not surprising because of the large difference in cell sizes between the two modules.

Cycle 49 and 51 [Figures 11 and 13] were run with the module in a temperature chamber at 23 to $25^{\circ} \mathrm{C}$, with chamber temperature controlled by a thermocouple (insulated from chamber air) mounted on the battery. This control scheme originally resulted from a procedural oversight, but it provided an interesting comparison, so it was repeated in Cycle 51 to record the chamber temperature as well. The measured battery temperature 
rose to only 30 to $32^{\circ} \mathrm{C}$ during these tests, but the electrical performance appears to be indistinguishable from Cycle 48. The temperature graph for Cycle 51 indicates that the chamber temperature reached a minimum of $-10^{\circ} \mathrm{C}$ in the process of holding the battery temperature rise to 5 to $7^{\circ}$.

Cycle 50 [Figure 12] was identical to Cycle 48 except that the module was inside a $25^{\circ} \mathrm{C}$ chamber. The temperature in this test reached $52^{\circ} \mathrm{C}$, which suggests that the air circulation in the chamber is somewhat less than that achieved by simply blowing room air over the module. It also verified that the large temperature increase measured in Cycle 48 was genuine.

\section{Electrical Behavior}

Power behavior [Figures 15, 16, 17, and 18] is essentially identical for all four tests, except that Cycles 49 and 51 (the lower temperature tests) show the effect of more voltage clamping during the regen steps early in segment 4 . They differ from $8 \mathrm{D}$ Test 2 [Figure 19] only because the $8 \mathrm{D}$ module never encountered any voltage clamping due to its larger cell size. The net energy behavior [also Figures 15-18] is also nearly the same for all 4 tests. (Any change in capacity that may have resulted from temperature differences is not obvious here, because the battery is not discharged completely in these tests.) The data show that segment 2 is not a very good approximation to "zero net energy" operation for these tests, unlike the corresponding $8 \mathrm{D}$ test using the same tester program. This is apparently because the Optima module is not able to deliver enough current (while staying above its minimum voltage) at the low state of charge in segment 2 to reach the programmed power values on large discharge steps. The result of this is that net energy is being added to the battery during this period, where the $8 \mathrm{D}$ battery shows a slight decrease in net energy. The net energy to the battery during segment 4 is very little changed in either the Optima or 8D tests.

The current behavior for all tests [Figures 20-24] essentially mirrors the power data, except for minor variations resulting from voltage clamping. The net ampere-hour graphs [also Figures 20-24] show the same behavior as the net energy, although all are of course lower (i.e. flatter or relatively decreasing) during segments 2 and 4 because of chargedischarge inefficiencies. The graphs showing ampere-hours for complete cycles indicate that the effective overcharge for the 8D module (about 12 ampere-hours) [Figure 26] is much greater than for the Optima tests (about 1 ampere-hour) [Figure 25]; this is not surprising because the $8 \mathrm{D}$ module is a flooded design.

A number of observations can be made about voltage behavior during the tests:

- The 8D module [Figure 31] is essentially always limited by the discharge current capabilities of the tester, rather than by the battery itself.

- $\quad$ The Optima module tests [Figures $27,28,29,30$ ] show voltage-clamping (i.e. current limiting by the module) for all the peak discharge steps in segments 1 and 2 for all tests, as well as for most of the $62.5 \%$ steps which follow the peaks.

- For segment 4, none of the Optima tests show voltage clamping until near the end of the 1-hour duration. (Note, however, that all these peaks are inherently limited 
by the $500 \mathrm{~A}$ tester maximum.) One possible explanation for this is that the module is at a higher state of charge during segment 4 than it was even at the beginning of the test; however, this is inconsistent with the net ampere-hour values, which are negative and decreasing through all of segment 4 . The more likely cause is that the module's temperature is higher in segment 4 than at the start of the test, lowering its resistance slightly. There is no visible difference in this regard between the higher and lower temperature tests, but it should be noted that the measured module temperature is on the case rather than inside the module.

- Optima regen current acceptance is limited by voltage clamping at the beginnings of segments 1 and 4 for all tests. This effect is much more severe for the lower temperature tests Cycles 49 and 51 [Figures 28 and 30]. The fact that it goes away during segment 4 seems to imply that the state-of-charge of the module is decreasing, which agrees with both the net ampere-hour data and $\mathrm{kWh}$ data.

- The voltage rise during the constant power segment 3 is very different for the two test temperature conditions. Although the starting voltage is about the same in every case, the ending voltage is much higher in the lower temperature tests [Figures 28 and 30], and the rise is much less linear with time. Further, the more severe voltage limiting at the start of segment 4 for these tests seems to imply that the battery is at a higher state of charge. Since segment 3 is done for a fixed number of ampere-hours, this could mean that the charge efficiency/acceptance is better at lower temperature (at least at this rather high charge rate approaching 40 W/kg.) This is a non-intuitive result, and a more likely explanation is that the state of charge is also higher at the beginning of segment 3 , even though the net A-h and net $\mathrm{kWh}$ graphs do not indicate this. The regen voltage behavior near the end of segment 2 supports this idea, although it could be due to the lower temperature.

\section{Procedural Results and Issues}

The few tests performed to date on the Optima and $8 \mathrm{D}$ modules have provided valuable feedback with respect to the practicality of a complex hybrid test cycle. Some of the issues raised are as follows:

- The capability to maintain a constant (or even approximately constant) intermediate stateof-charge (SOC) on a lead-acid battery for an extended period of high power operation is affected by the size and power capability of the battery, its temperature behavior, and its interaction with any test equipment limitations. Even if a tester has the capability to adjust its demands "on the fly" (which many do not), determining battery SOC accurately during a dynamic test is at best computationally intensive and at worst impossible. Other battery technologies may be less difficult in this regard, but the problem is likely to exist in some form nonetheless. This suggests that a hybrid test cycle should not rely heavily on being able to do this. For example, extended periods of operation near $80 \%$ DOD could yield behavior for one battery that appears very different from a quite similar one, if one drifts toward $90 \%$ DOD while the other drifts toward $70 \%$ using the same test cycle. This problem can be addressed in perhaps three ways, in increasing order of difficulty: limiting "zero net energy" operation to the middle of the SOC range; "tuning" the test profile for the specific battery under test; or controlling test power dynamically such that constant 
SOC is maintained. This problem is simpler for "capacitor-like" devices because their energy content is more easily measured.

- Both SOC maintenance and the ability to reach high specific powers are impacted by the relationship between tester current/power limits and the size of the battery being tested. The Optima module, for example, would require 1000A discharge currents to reach even $500 \mathrm{~W} / \mathrm{kg}$ peaks at the minimum module voltage. This problem is ultimately selfcorrecting in that a development program will eventually build the appropriate size devices for the application. However, screening technology candidates (especially existing designs) will certainly require a degree of "art" because of this. Fortunately for test laboratories, existing battery candidates are unlikely to be capable of much greater than $500 \mathrm{~W} / \mathrm{kg}$ power levels in the foreseeable future.

- Control of temperature will be a more severe problem for hybrid life cycle testing than for conventional battery testing, because of both the high powers involved and the need to operate for extended periods with little or no net energy removed from the battery. For example, the temperature rate-of-rise observed during the Optima tests is only slightly lower during the "zero net energy" segments than the conventional DST segments. (This is true even where substantial cooling was provided.) A battery with this type of thermal behavior may not in fact be suitable for hybrid applications, but the screening process still has to be done in a controlled fashion. It is suggested that a hybrid life cycle procedure should make use of whatever cooling is required to maintain the battery within its design operating range, and that both the thermal behavior and the cooling energy requirements should be characterized separately.

\section{Outline of FY-1996 Proposed Activities}

\section{Procedure Development}

- The existing procedure will be refined to address the SOC maintenance and thermal issues discussed in the previous section, along with any other concerns or suggestions which may result from review of the results reported here. (For example, application-oriented feedback is needed with respect to the reasonableness of the lengths of the various segments and the criteria for changing from one to another.)

- The procedure will be exercised with other types of batteries (i.e. non-lead-acid), and also with capacitor devices as available, to identify other concerns or behaviors which would affect its practicality.

- A less complex procedure for power assist mode (only) operation will be defined and exercised using one or more of the same devices already tested. If suitable test channels are available, comparative cycle life will be measured using the two methods.

\section{High Power Battery Testing}

Commercially available battery candidates will continue to be screened for high power performance (and for life where test capabilities are available.) Candidates include the following: 
- Six additional 2-cell packs of Sony lithium ion cells have been acquired, and a small number of Maccor test channels may be available for use "between and around" USABC deliverable testing. These will be subjected to a revised version of the procedure which will take into account the limitations of the Maccor testers, which are capable of high specific power on cells this size but have constraints on program complexity. It may be necessary in some cases to perform tests using individual segments of the full test.

- $\quad$ Since the previous Sony cells may possibly have been damaged by improper charging (or even tester malfunction), and Sony will not provide any information on their charge strategy, a limited investigation will be attempted of Sony's charger. (The charging control electronics for the Sony battery packs is actually incorporated in the packs themselves.)

- Sony has recently announced an EV-size lithium ion battery, which should be tested as part of this project if samples actually become available. The announced specifications for their module ( $100 \mathrm{~A}-\mathrm{h}$, nearly $30 \mathrm{~kg}$ ) imply a large cell size, which will be difficult to test at the very high specific powers desired. Some investigation of the potential for paralleling multiple testers will be pursued in connection with this.

- $\quad$ INEL has 6 Electrosource Horizon modules available, which will be made into a 72 volt pack to be tested using available test equipment.

- Thirty Delco (Delphi) Impact-type modules modules have been obtained from a current production run for various uses in the laboratory, and the high power capability of these will be investigated.

Additionally, USABC developers, including those involved in the Phase 1 PNGV efforts which are just beginning, will be offered the opportunity to have samples subjected to the high power test procedure(s). It is also possible that some test samples supplied for conventional USABC testing might be available for high power performance testing after other planned testing is completed. (This is obviously only likely to apply to test articles which are not life cycle tested.) This would provide some interesting data for comparison with the results using the conventional USABC test procedures.

A more detailed plan for the conduct of these activities during FY-1996 is in preparation and will be submitted to the Department of Energy for review at a later date.

\section{References}

1. Hunt, Sutula, and Heitner, "Energy Storage Requirements and Testing for Hybrid Electric Vehicles," Paper 95-11, 30th Intersociety Energy Conversion Engineering Conference, Orlando, Florida, August, 1995. 
Table 1

Summary Test Results for Sony NP-500H Lithium Ion Cells

\begin{tabular}{|c|c|c|c|c|c|c|c|c|c|c|c|c|c|c|}
\hline Procedure & Description & Units & c1 & C2 & C3 & $\mathrm{C}_{4}$ & C5 & $\mathrm{C6}$ & C7 & C8 & C9 & C10 & C11 & C12 \\
\hline & $\begin{array}{c}\text { Mass } \\
\text { Volume }\end{array}$ & g & $\begin{array}{l}40.7 \\
0.017\end{array}$ & 40.7 & 40.8 & 40.8 & 40.4 & 40.4 & 40.5 & 40.2 & 40.4 & 40.3 & 40.3 & 40.3 \\
\hline $\begin{array}{l}\text { Constant } \\
\text { Current }\end{array}$ & $C_{3} / 3$ Capacity & $\begin{array}{c}\text { Ah } \\
\text { Wh/kg } \\
\text { Wh/l }\end{array}$ & $\begin{array}{l}1.10 \\
98 \\
236\end{array}$ & $\begin{array}{l}1.10 \\
98 \\
235\end{array}$ & $\begin{array}{l}1.04 \\
92 \\
221\end{array}$ & $\begin{array}{l}1.03 \\
89 \\
215\end{array}$ & $\begin{array}{l}1.02 \\
88 \\
211\end{array}$ & $\begin{array}{l}1.10 \\
98 \\
237\end{array}$ & $\begin{array}{l}1.03 \\
100 \\
240\end{array}$ & $\begin{array}{l}0.98 \\
85 \\
204\end{array}$ & $\begin{array}{l}1.04 \\
91 \\
216\end{array}$ & Shorted & $\begin{array}{l}1.03 \\
90 \\
216\end{array}$ & $\begin{array}{l}1.02 \\
89 \\
213\end{array}$ \\
\hline $\begin{array}{r}\text { Constant } \\
\text { Current }\end{array}$ & $\begin{array}{c}\mathrm{C}_{3} / 3 \text { Charge } \\
\text { Return }\end{array}$ & $\begin{array}{l}\% \text { Ah } \\
\% \text { Wh }\end{array}$ & $\begin{array}{l}100 \\
108\end{array}$ & & & & & & & & & & & \\
\hline $\begin{array}{l}\text { Constant } \\
\text { Current }\end{array}$ & $\begin{array}{l}\mathrm{C}_{2} / 2 \text { Capacity } \\
\mathrm{C}_{1} / 1 \text { Capacity }\end{array}$ & $\begin{array}{l}\text { Ah } \\
\text { Ah }\end{array}$ & $\begin{array}{l}1.1 \\
1.1\end{array}$ & $\begin{array}{l}1.1 \\
1.1\end{array}$ & & & & $\begin{array}{l}1.1 \\
1.1\end{array}$ & & & & & & \\
\hline $\begin{array}{l}\text { Constant } \\
\text { Power }\end{array}$ & $\begin{array}{l}C P \text { a } E_{3} / 3 \\
C P \text { a } E_{2} / 2 \\
C P \text { a } E_{1} / 1\end{array}$ & $\begin{array}{l}\text { Wh/kg } \\
\text { Wh/kg } \\
\text { Wh/kg }\end{array}$ & $\begin{array}{l}99 \\
98 \\
95\end{array}$ & $\begin{array}{l}99 \\
98 \\
95\end{array}$ & & & & & & & & & & \\
\hline $\begin{array}{c}\text { Peak } \\
\text { Power } \\
\text { Capability }\end{array}$ & $\begin{array}{l}\text { Peak Power } \\
30 \text { s a } 80 \% \text { DOD }\end{array}$ & $\begin{array}{l}W / \mathrm{kg} \\
W / l\end{array}$ & $\begin{array}{l}220 \\
530\end{array}$ & & & & & & & & & & & \\
\hline
\end{tabular}

Table 2

Summary Test Results for Optima Battery Modules

\begin{tabular}{|c|c|c|c|c|c|}
\hline Procedure & Description & Units & M1 & M2 & $M 3$ \\
\hline & $\begin{array}{l}\text { Mass } \\
\text { Volume }\end{array}$ & $\mathrm{kg}$ & $\begin{array}{l}20.99 \\
\text { Not measured }\end{array}$ & Leaked - not tested & 20.88 \\
\hline $\begin{array}{l}\text { Constant } \\
\text { Current }\end{array}$ & $C_{3} / 3$ Capacity & $\begin{array}{l}\text { Ah } \\
\text { Wh/kg }\end{array}$ & $\begin{array}{c}49.3 \\
28\end{array}$ & & $\begin{array}{c}49.5 \\
28\end{array}$ \\
\hline $\begin{array}{l}\text { Constant } \\
\text { Current }\end{array}$ & $\begin{array}{l}C_{3} / 3 \text { Charge } \\
\text { Return }\end{array}$ & $\begin{array}{l}\% \text { Ah } \\
\% \text { Wh }\end{array}$ & $\begin{array}{c}99 \\
107\end{array}$ & & $\begin{array}{l}101 \\
109\end{array}$ \\
\hline $\begin{array}{l}\text { Constant } \\
\text { Current }\end{array}$ & $\begin{array}{l}\mathrm{C}_{2} / 2 \text { Capacity } \\
\mathrm{C}_{1} / 1 \text { Capacity }\end{array}$ & $\begin{array}{l}\text { Ah } \\
\text { Ah }\end{array}$ & $\begin{array}{l}47.7 \\
44.4\end{array}$ & & $\begin{array}{l}45.7 \\
42.4\end{array}$ \\
\hline $\begin{array}{l}\text { Constant } \\
\text { Power }\end{array}$ & $\begin{array}{l}C P \text { a } E_{3} / 3 \\
C P \text { a } E_{2} / 2 \\
C P \text { a } E_{1} / 1\end{array}$ & $\begin{array}{l}\text { Wh/ } / \mathrm{kg} \\
\mathrm{Wh} / \mathrm{kg} \\
W h / \mathrm{kg}\end{array}$ & $\begin{array}{l}28 \\
27 \\
25\end{array}$ & & $\begin{array}{l}28 \\
26 \\
24\end{array}$ \\
\hline $\begin{array}{l}\text { Variable } \\
\text { Power }\end{array}$ & DST & Wh/kg & 19 & & 18 \\
\hline $\begin{array}{l}\text { Peak } \\
\text { Power }\end{array}$ & $\begin{array}{c}\text { Peak Power } \\
\text { 30s a } 80 \% \text { DOD }\end{array}$ & $W / k g$ & 80 (Note 1 ) & & \\
\hline
\end{tabular}

Note 1: Value interpolated from Figure 6 
$$
\cdot
$$ 


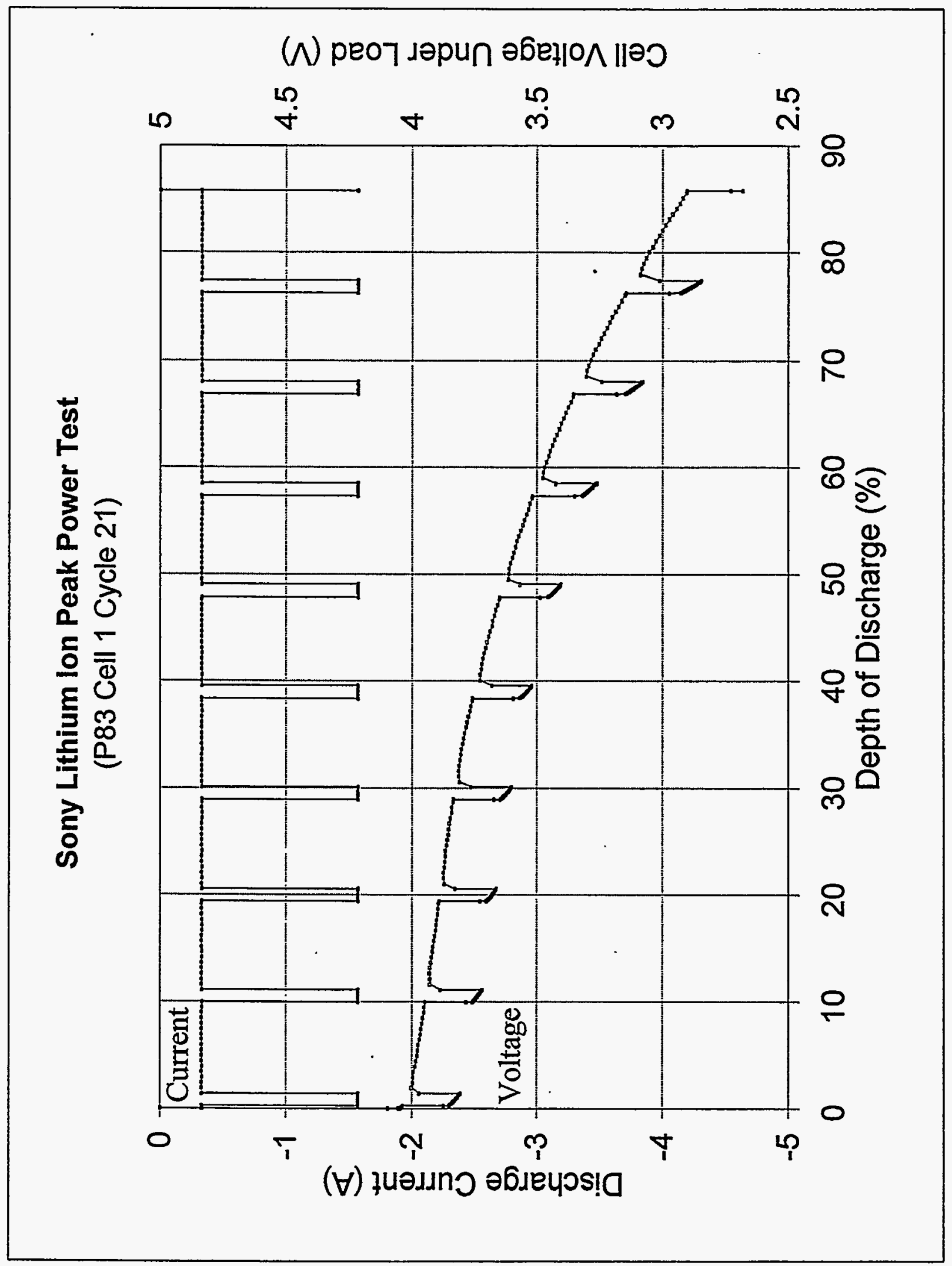

Figure 1. Sony lithium-ion peak power current and voltage. 


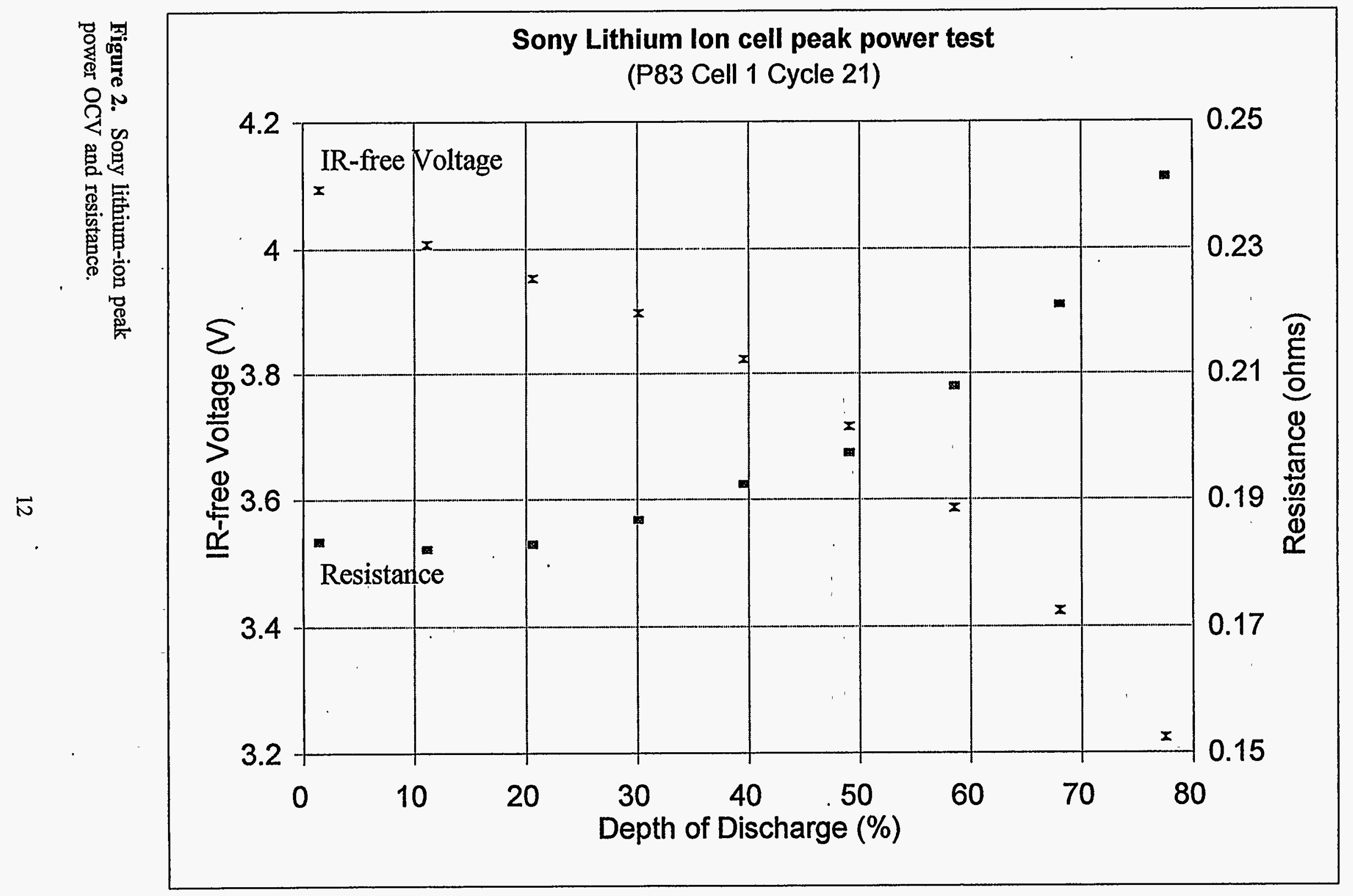




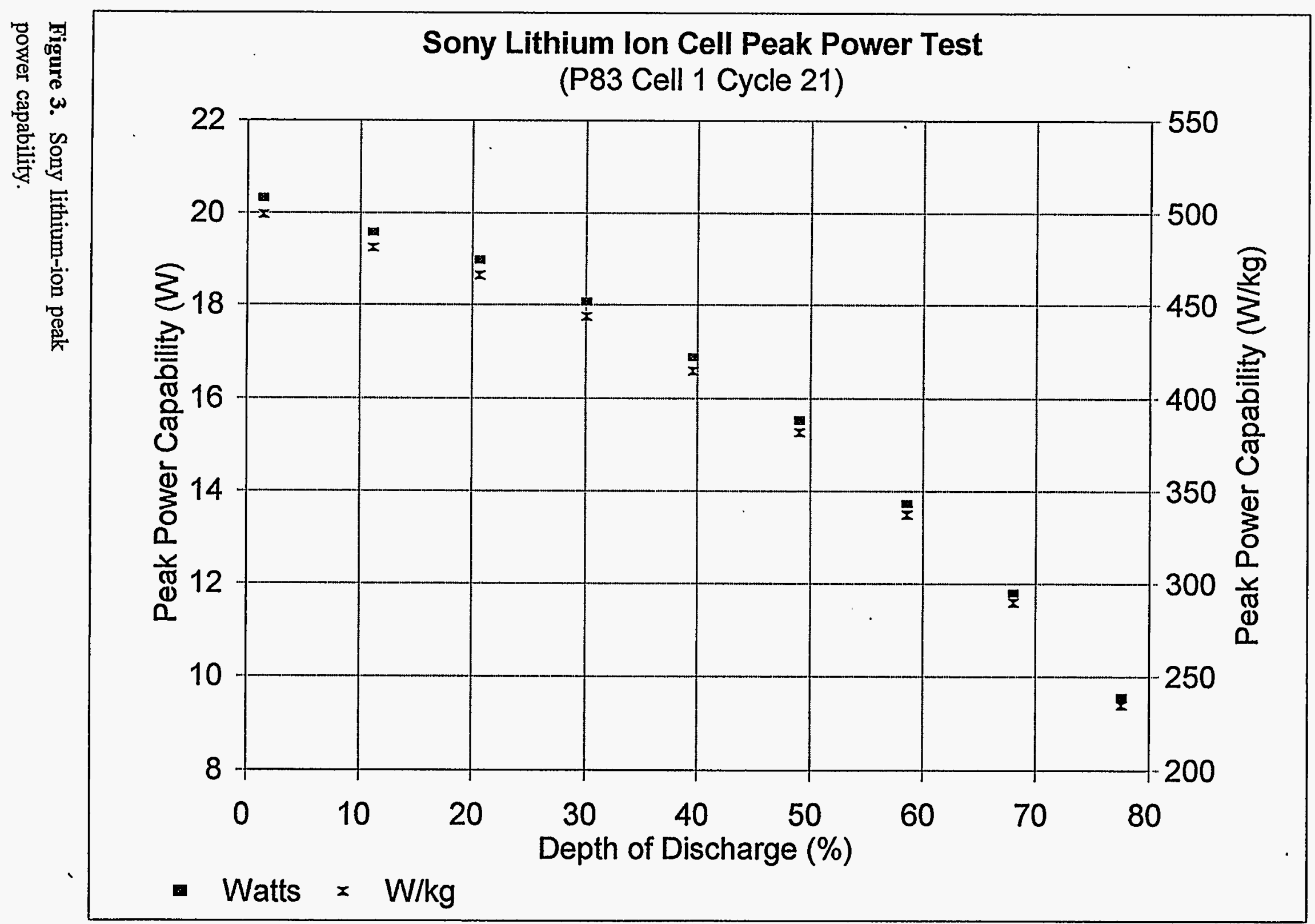




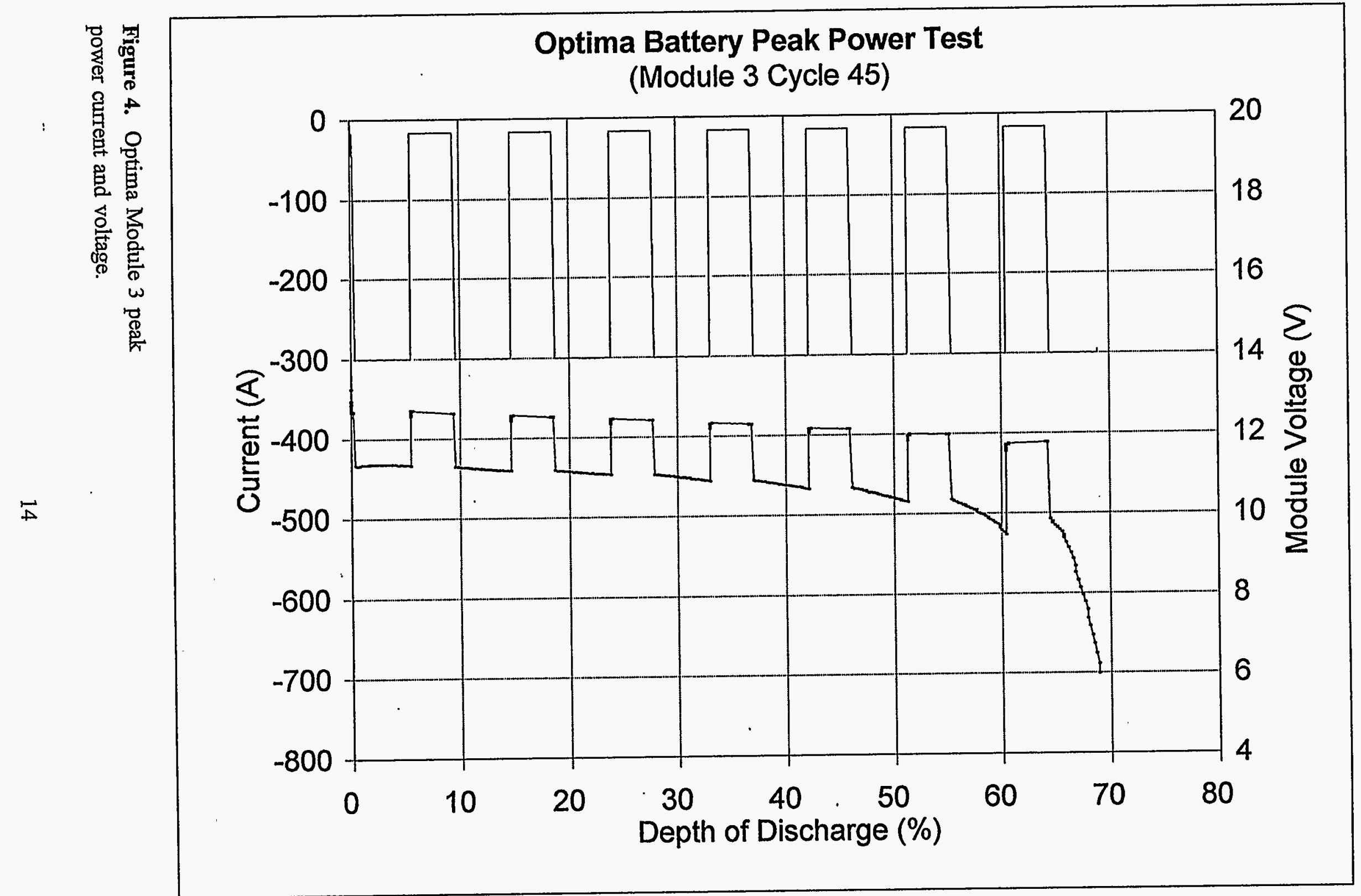




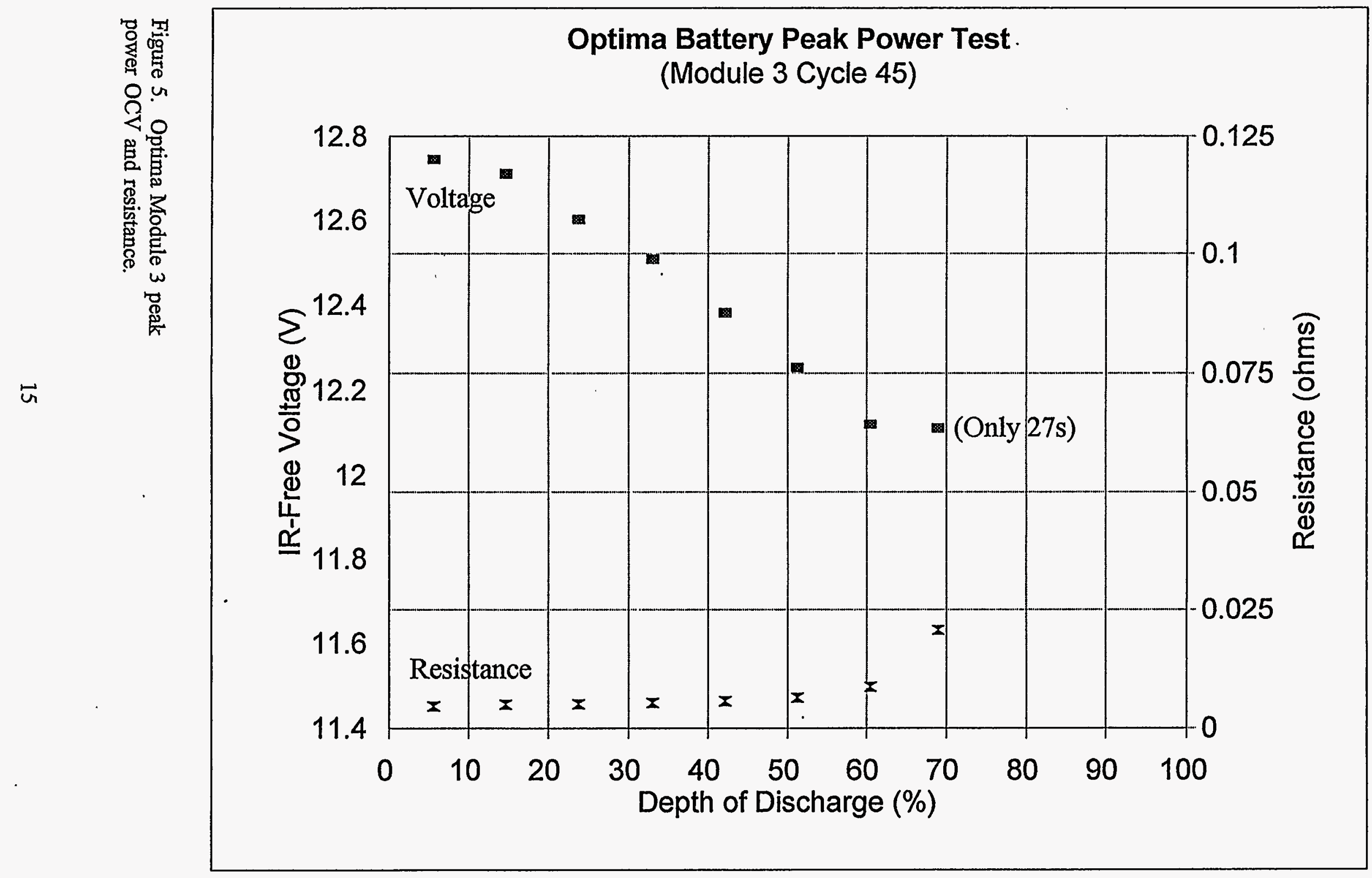




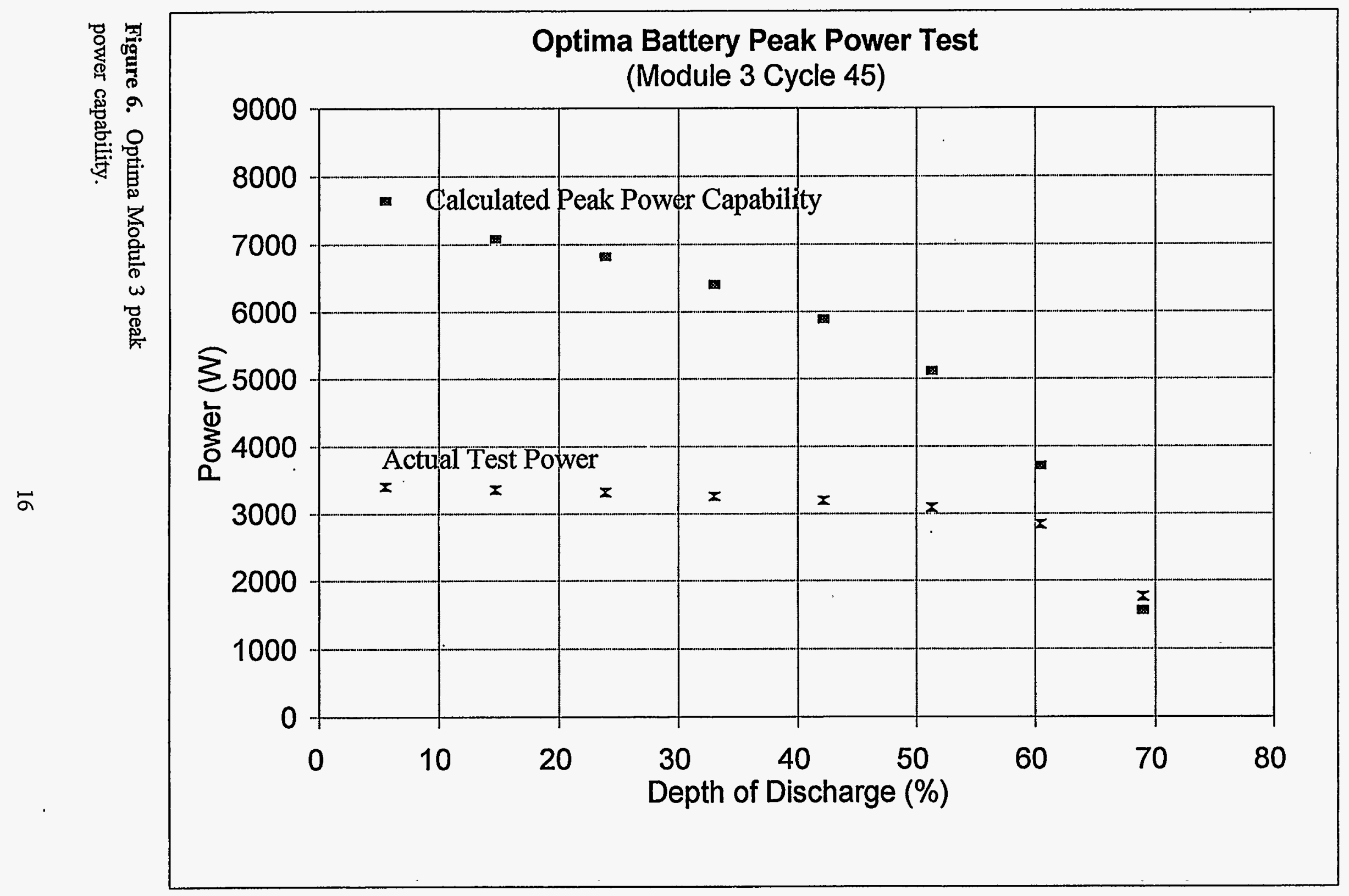




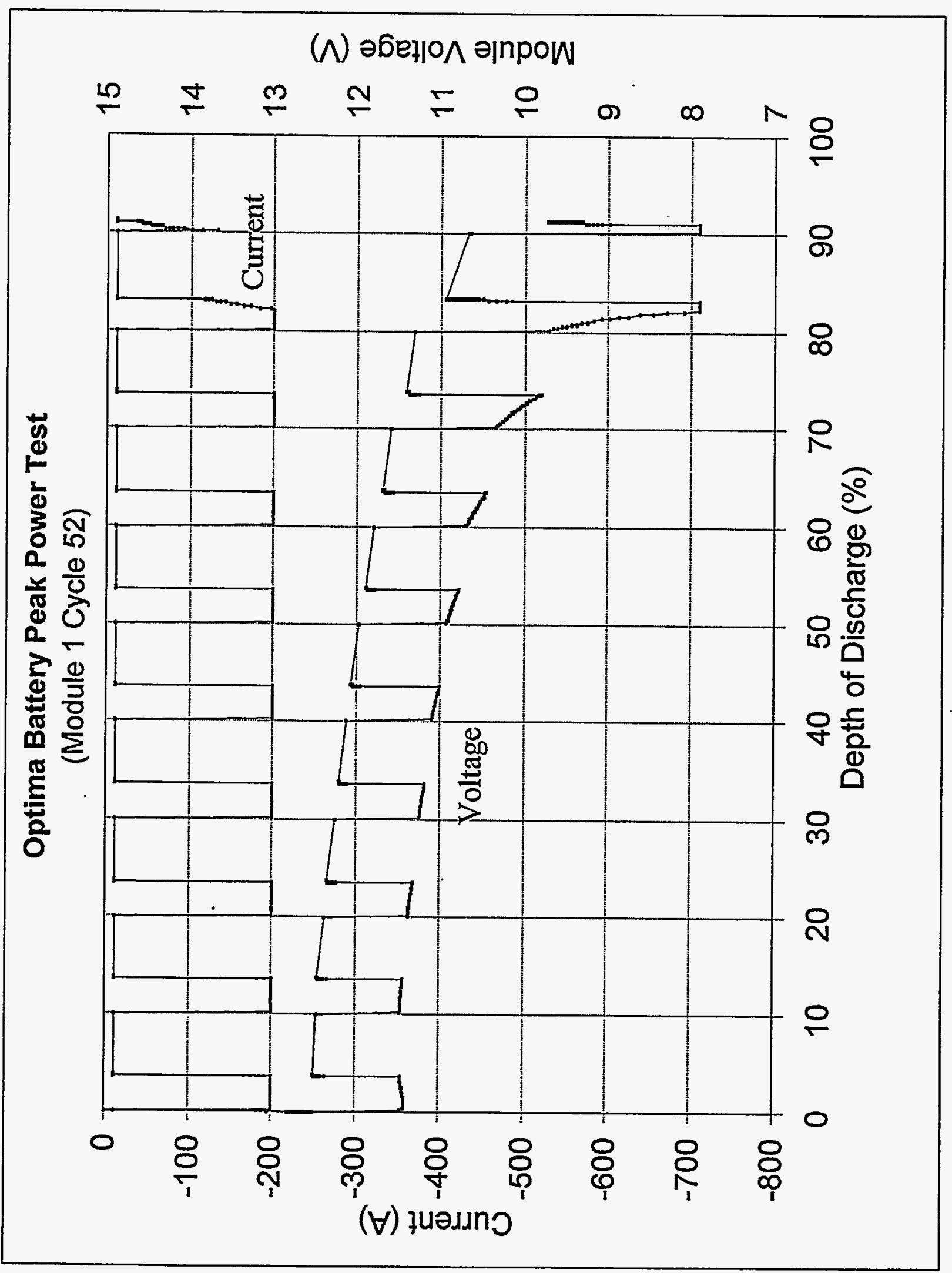

Figure 7. Optima Module 1 peak power current and voltage. 


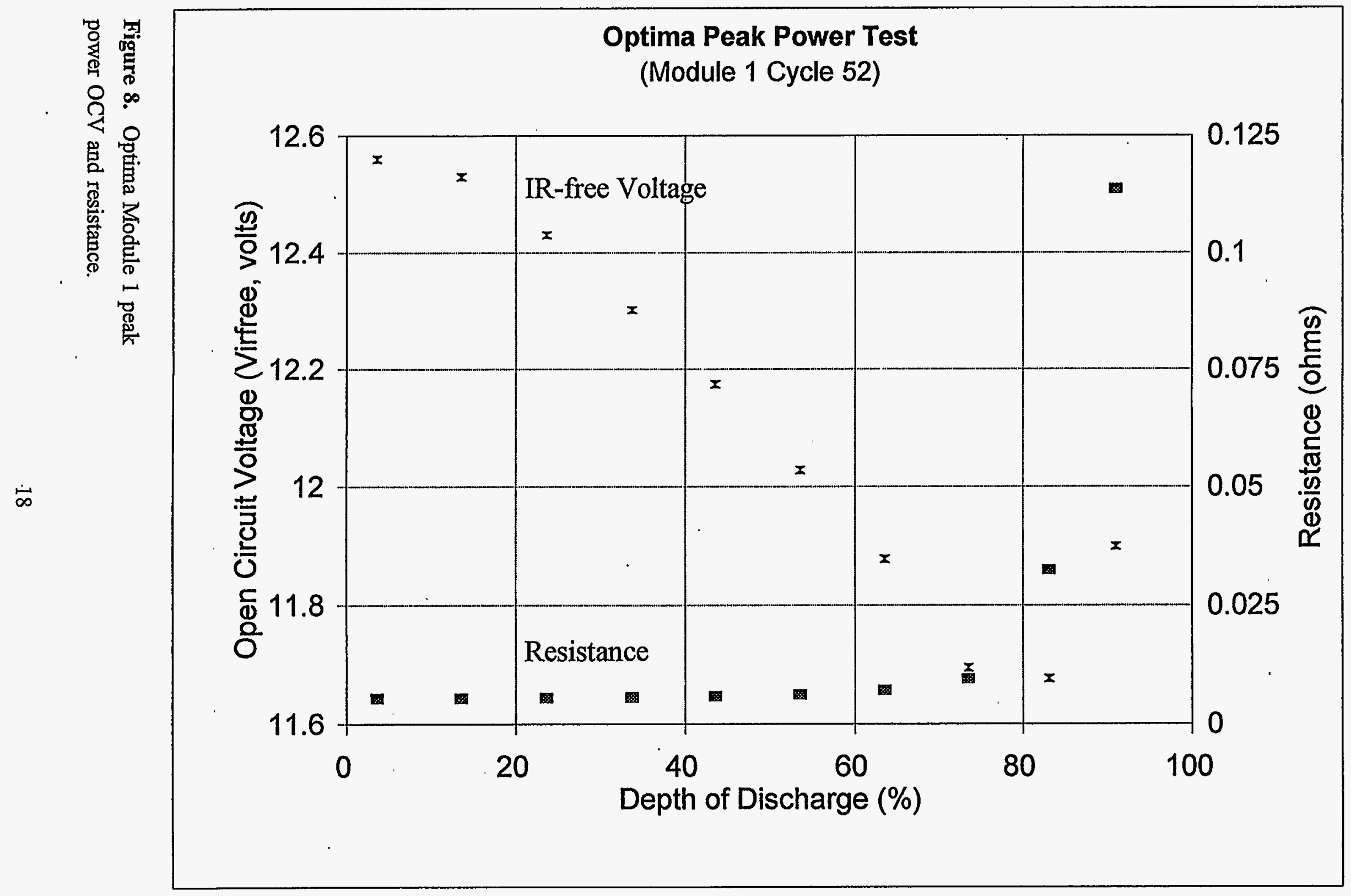




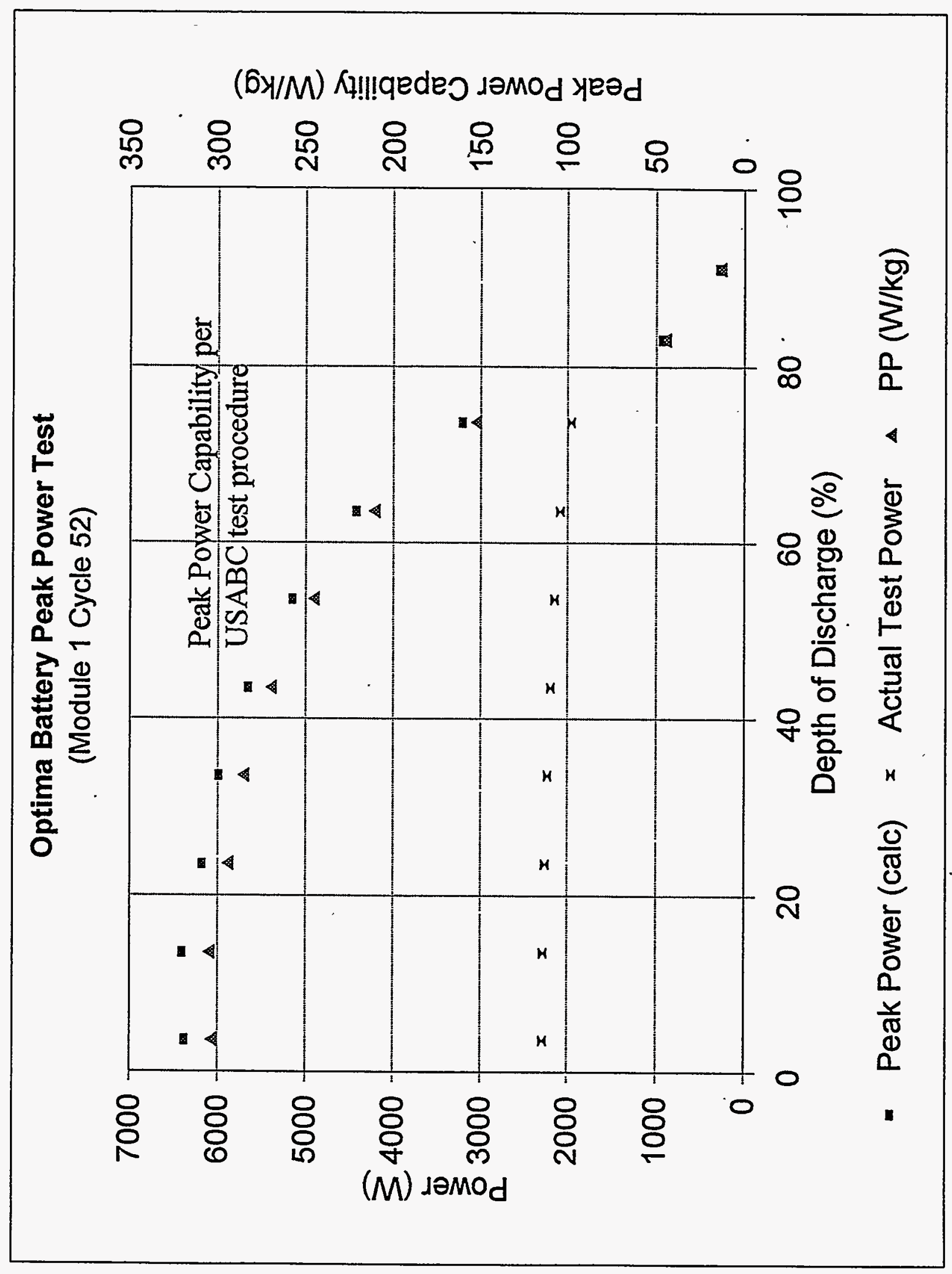

Figure 9. Optima Module 1 peak power capability 


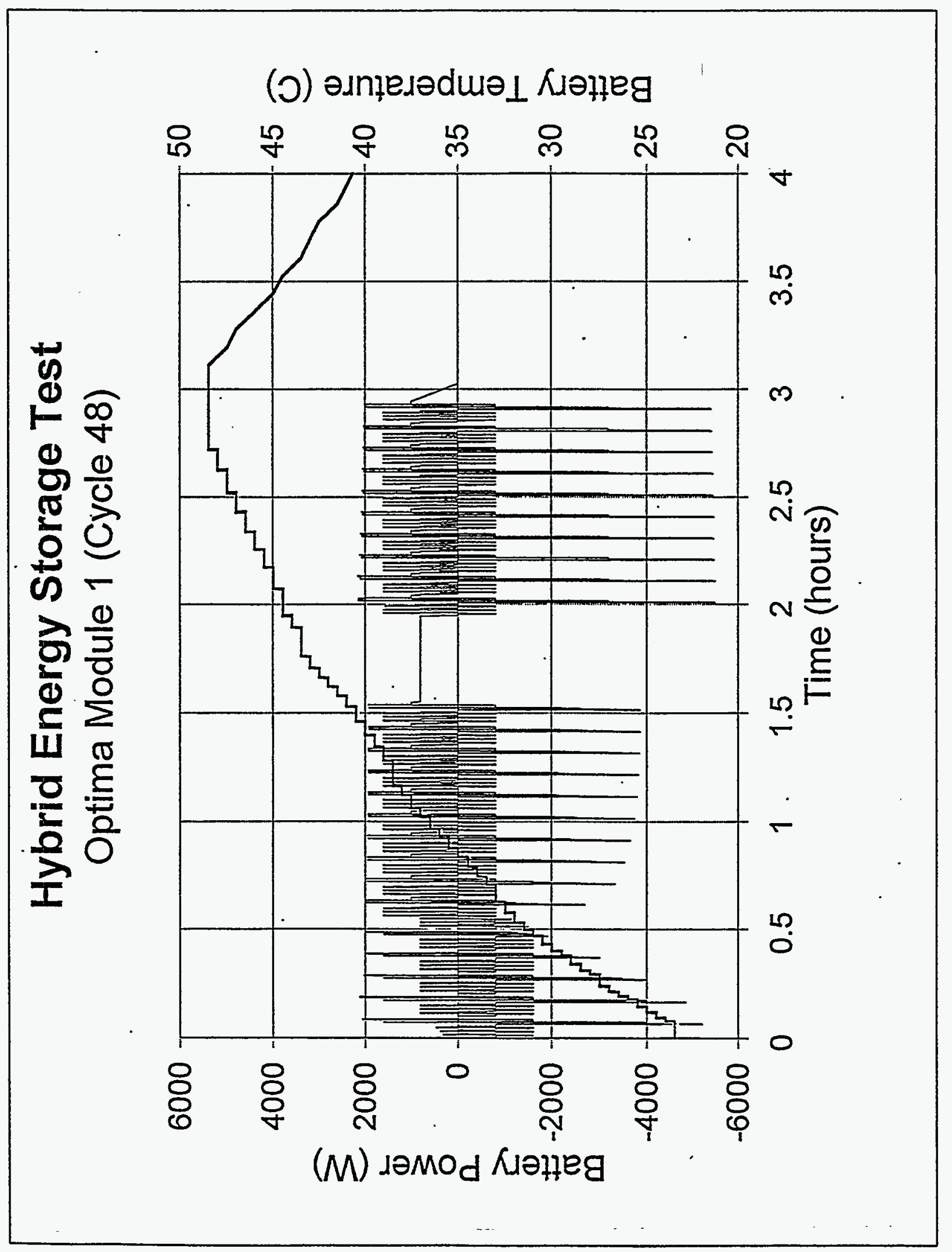

Figure 10. Optima Cycle 48 temperature and power. 


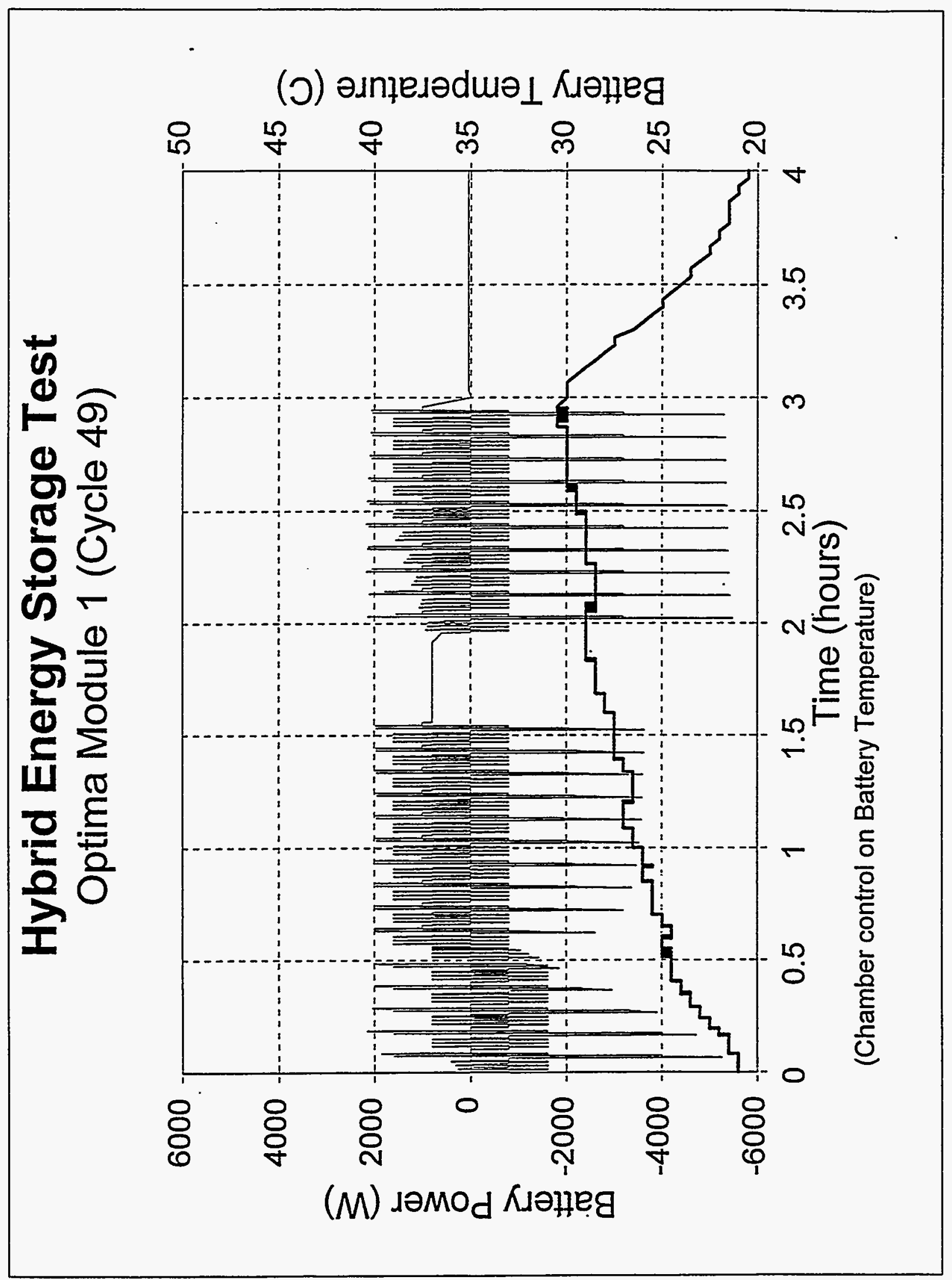

Figure 11. Optima Cycle 49

temperature and power. 


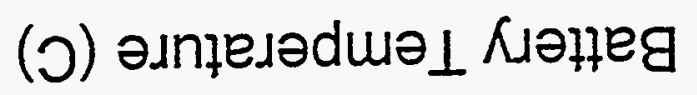

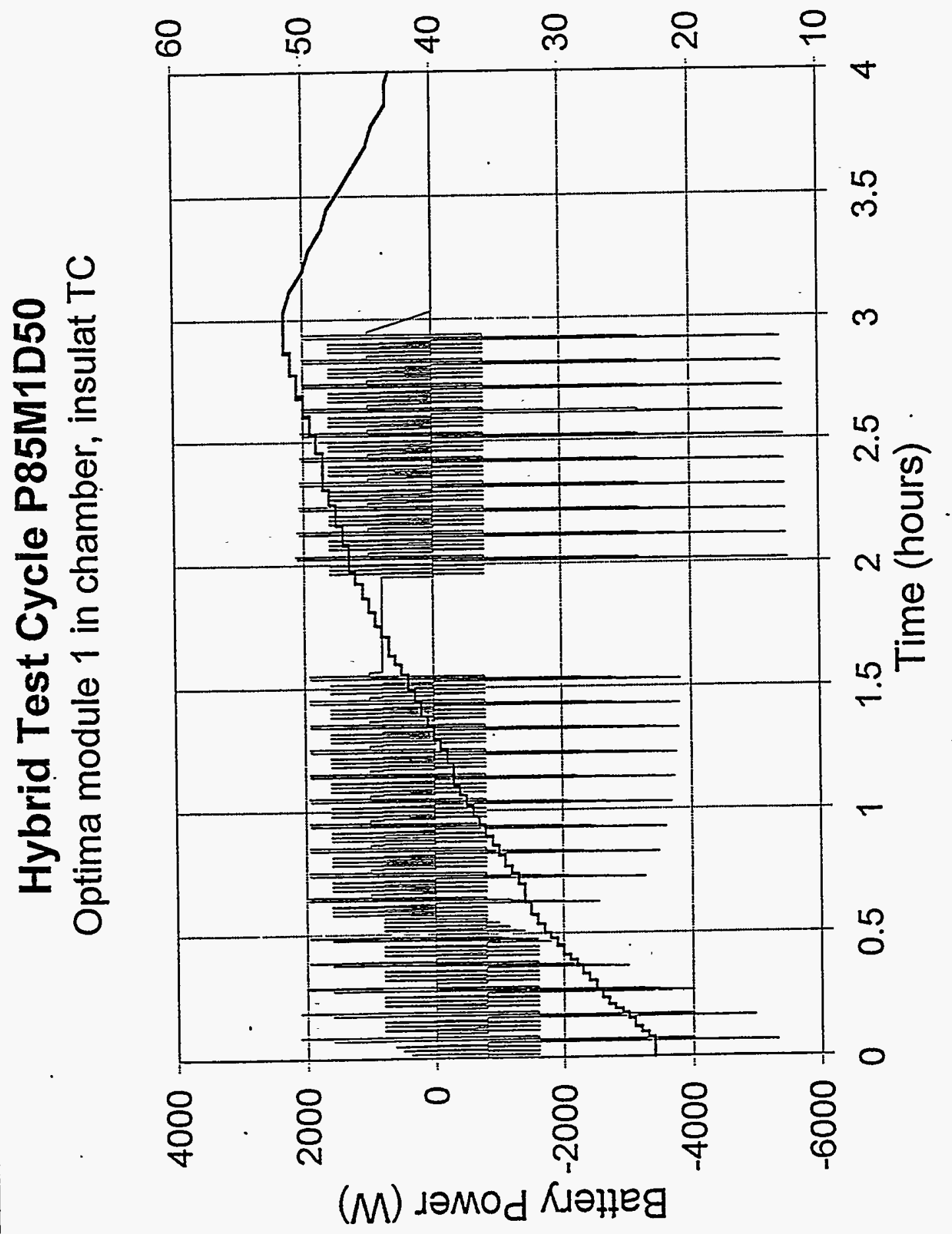

Figure 12. Optima Cycle 50 temperature and power. 


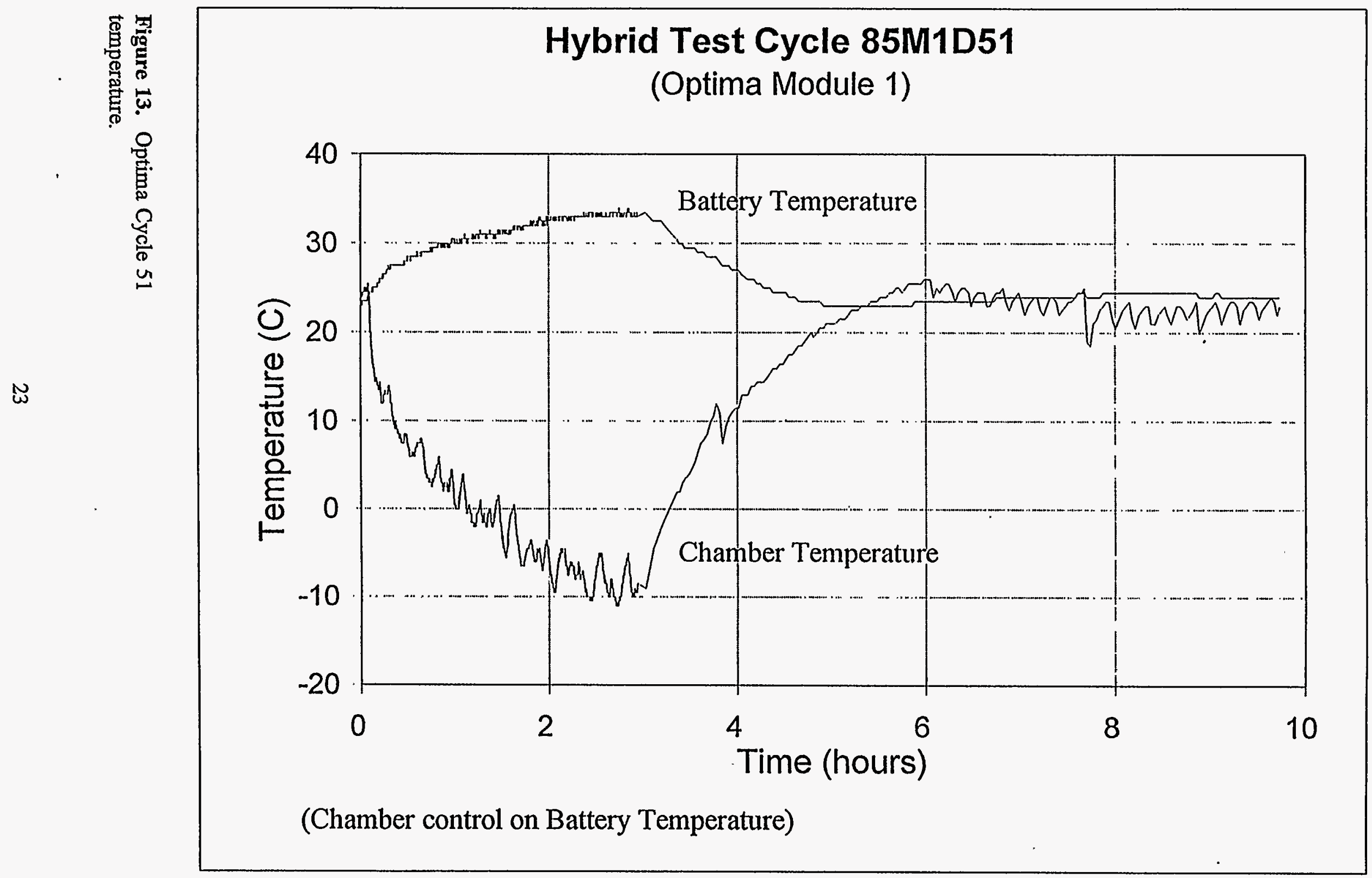




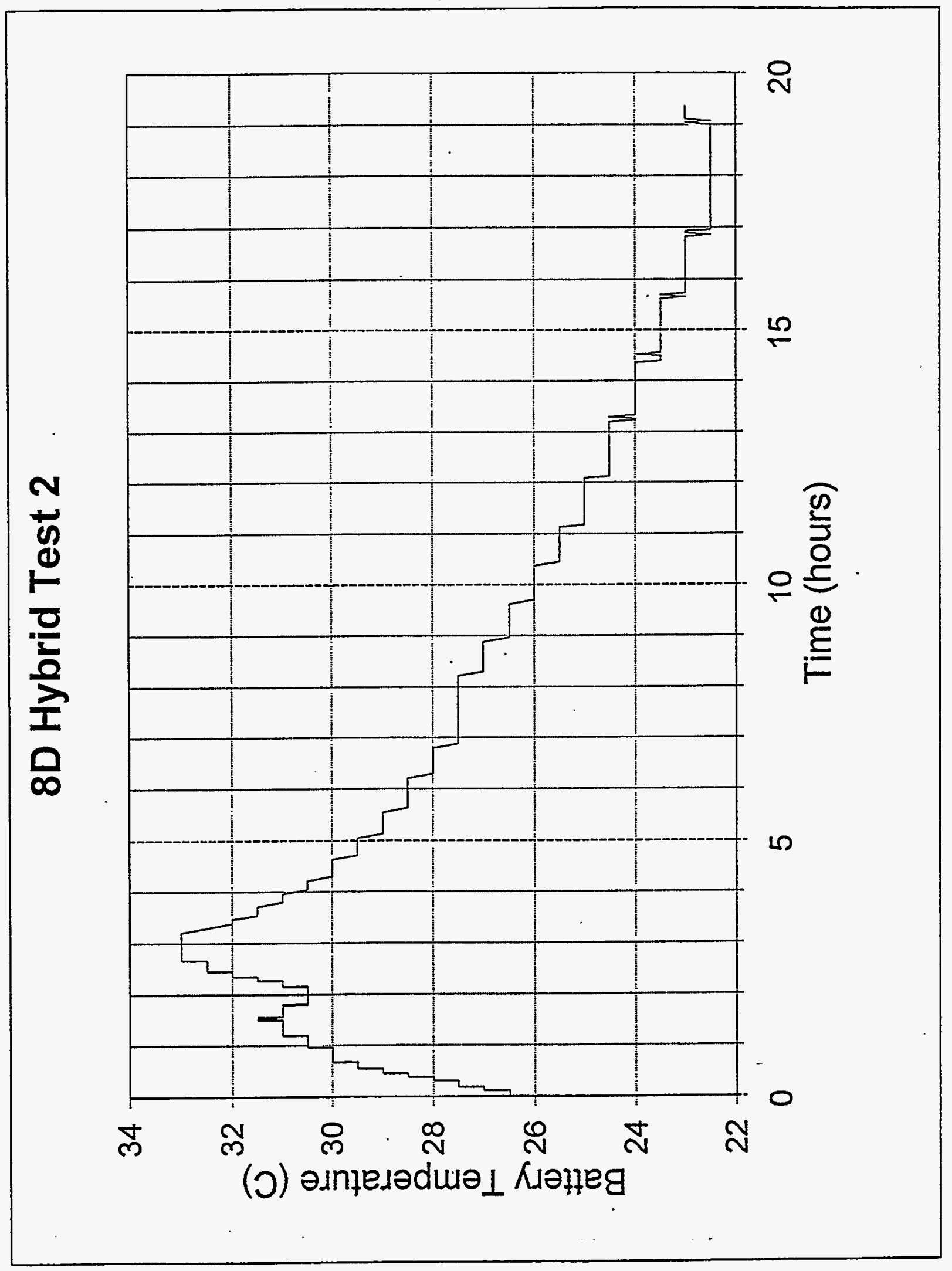

Figure 14. 8D Module temperature. 


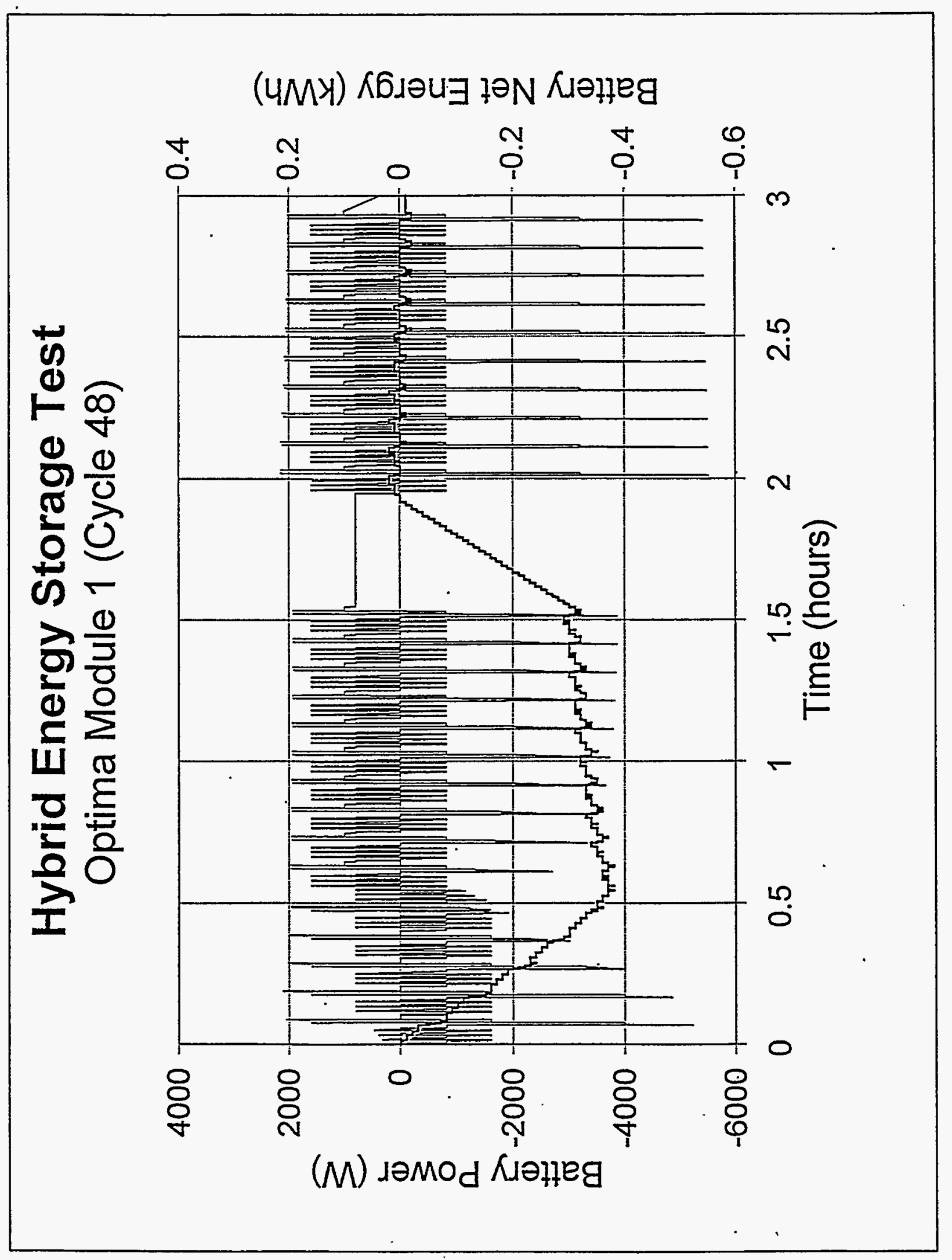

Figure 15. Optima Cycle 48 power and energy. 


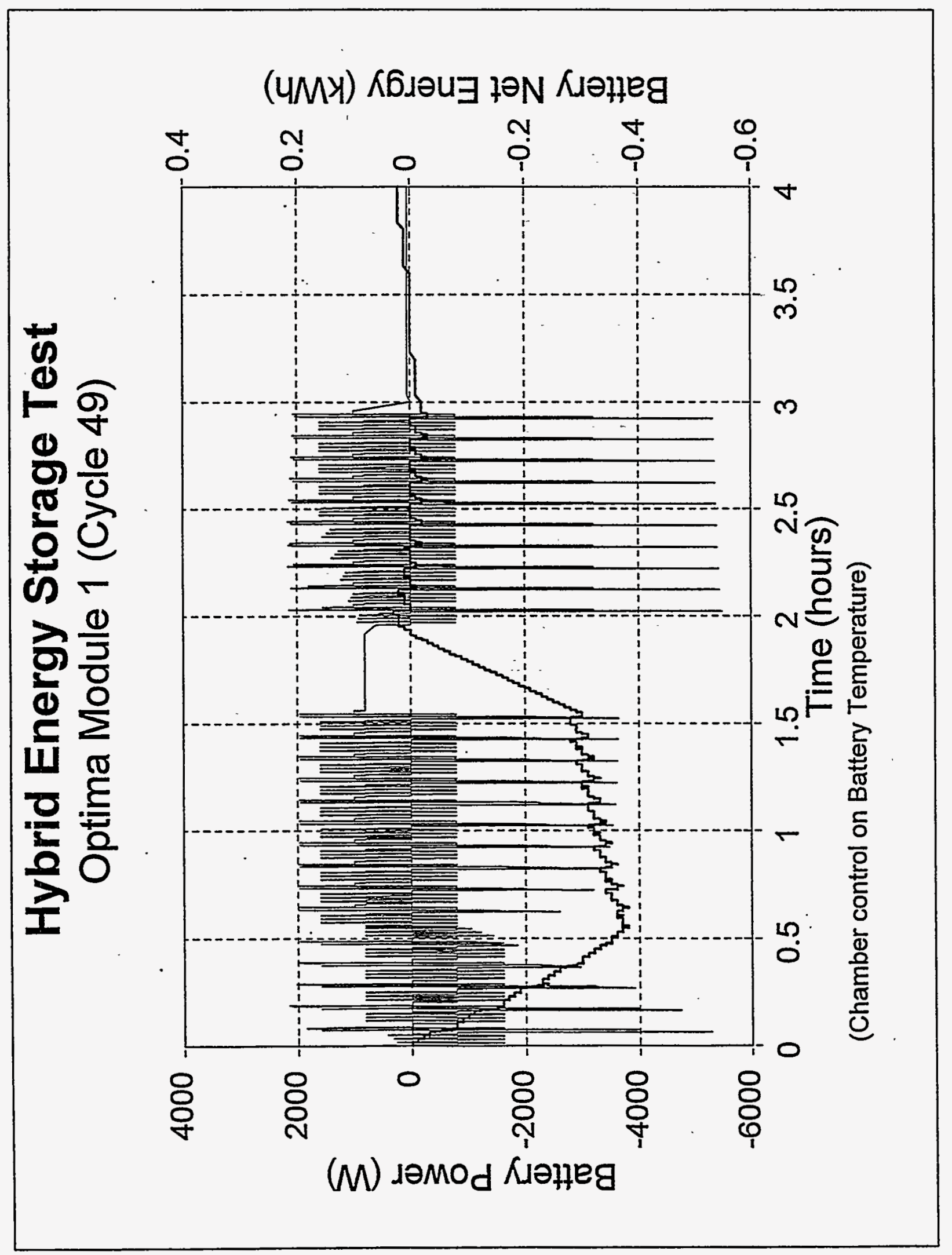

Figure 16. Optima Cycle 49 power and energy. 


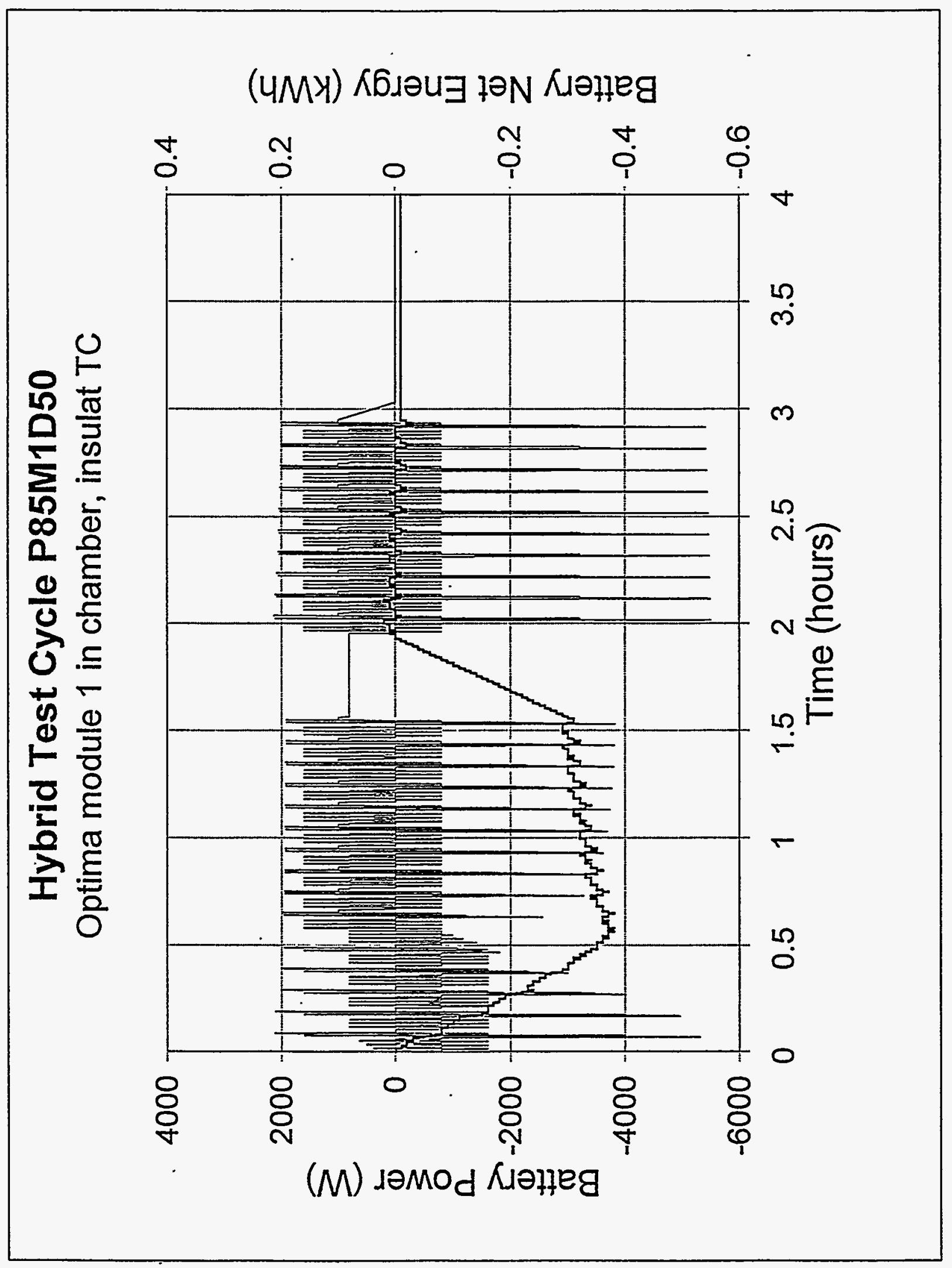

Figure 17. Optima Cycle 50 power and energy. 


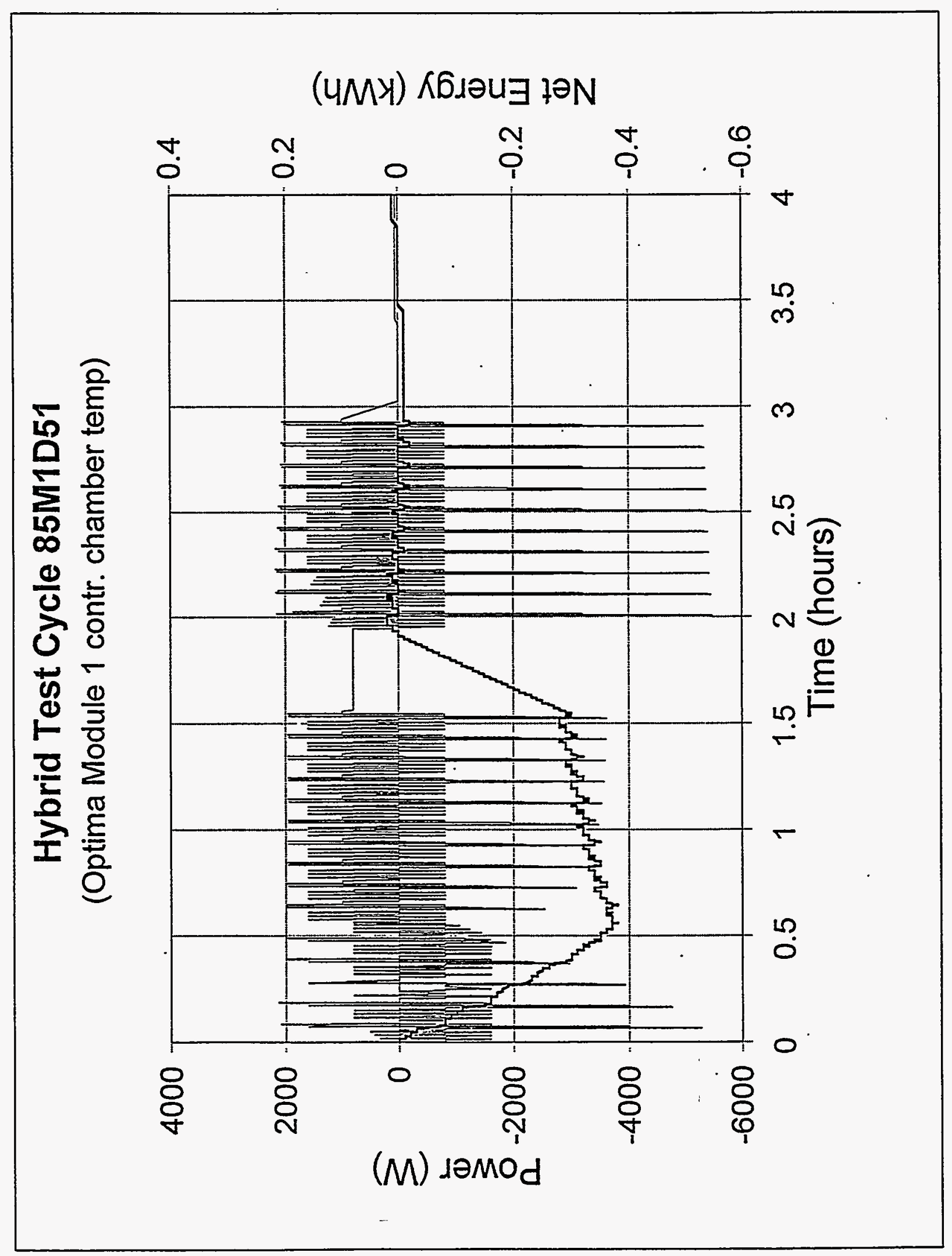

Figure 18. Optima Cycle 51 power and energy. 


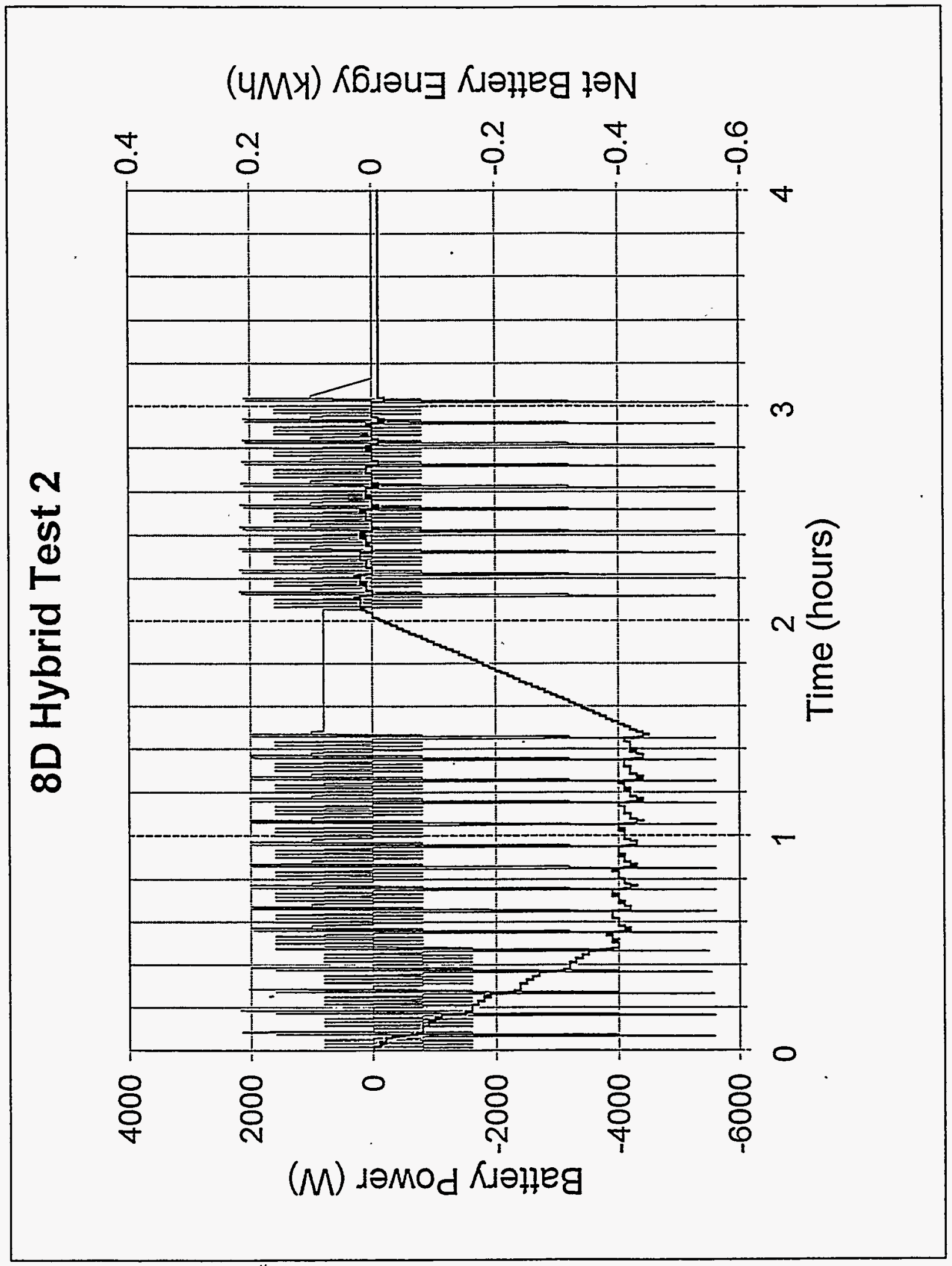

Figure 19. $8 \mathrm{D}$ Module power and energy. 


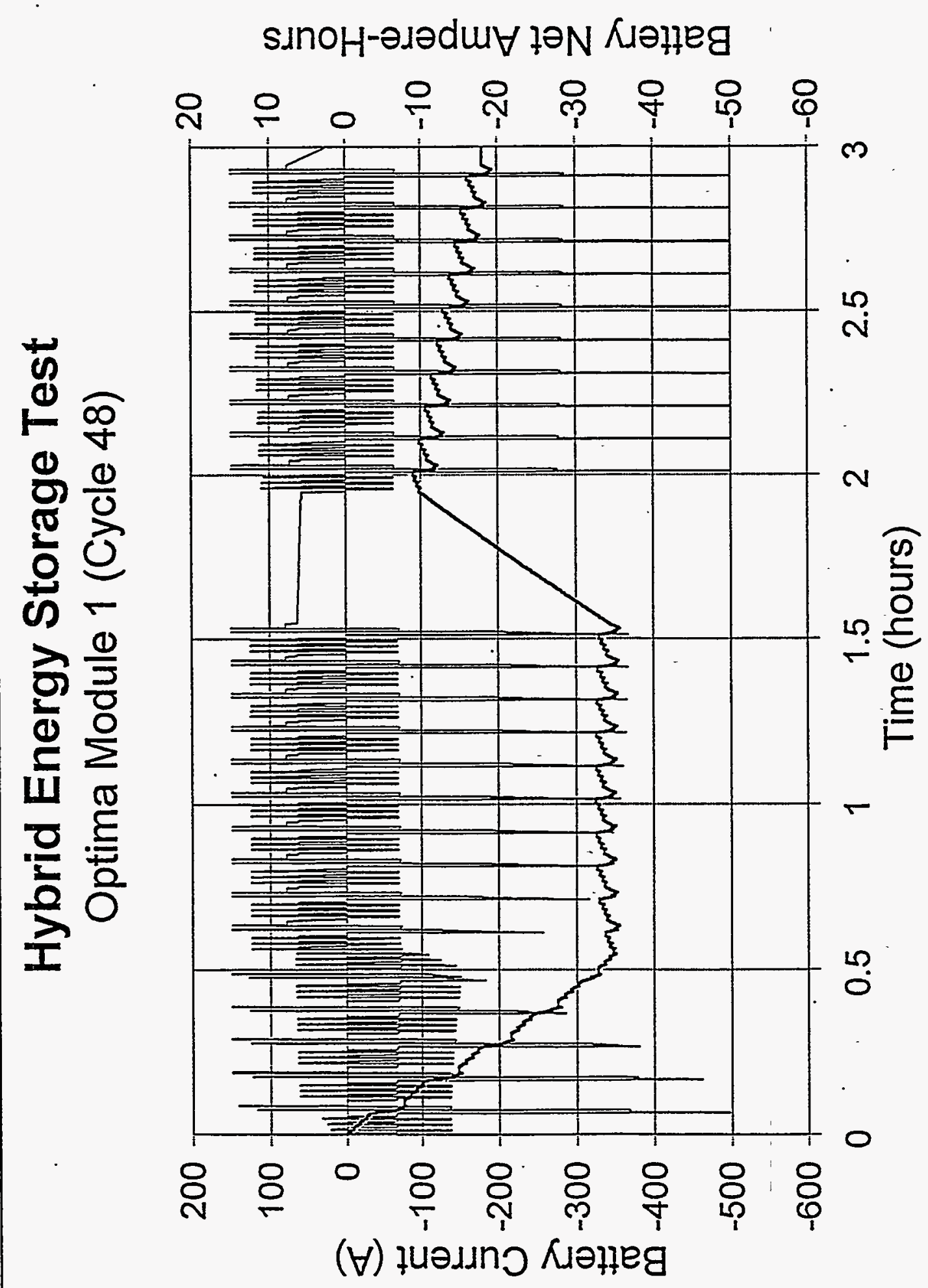

Figure 20. Optima Cycle 48 current and net A-h. 


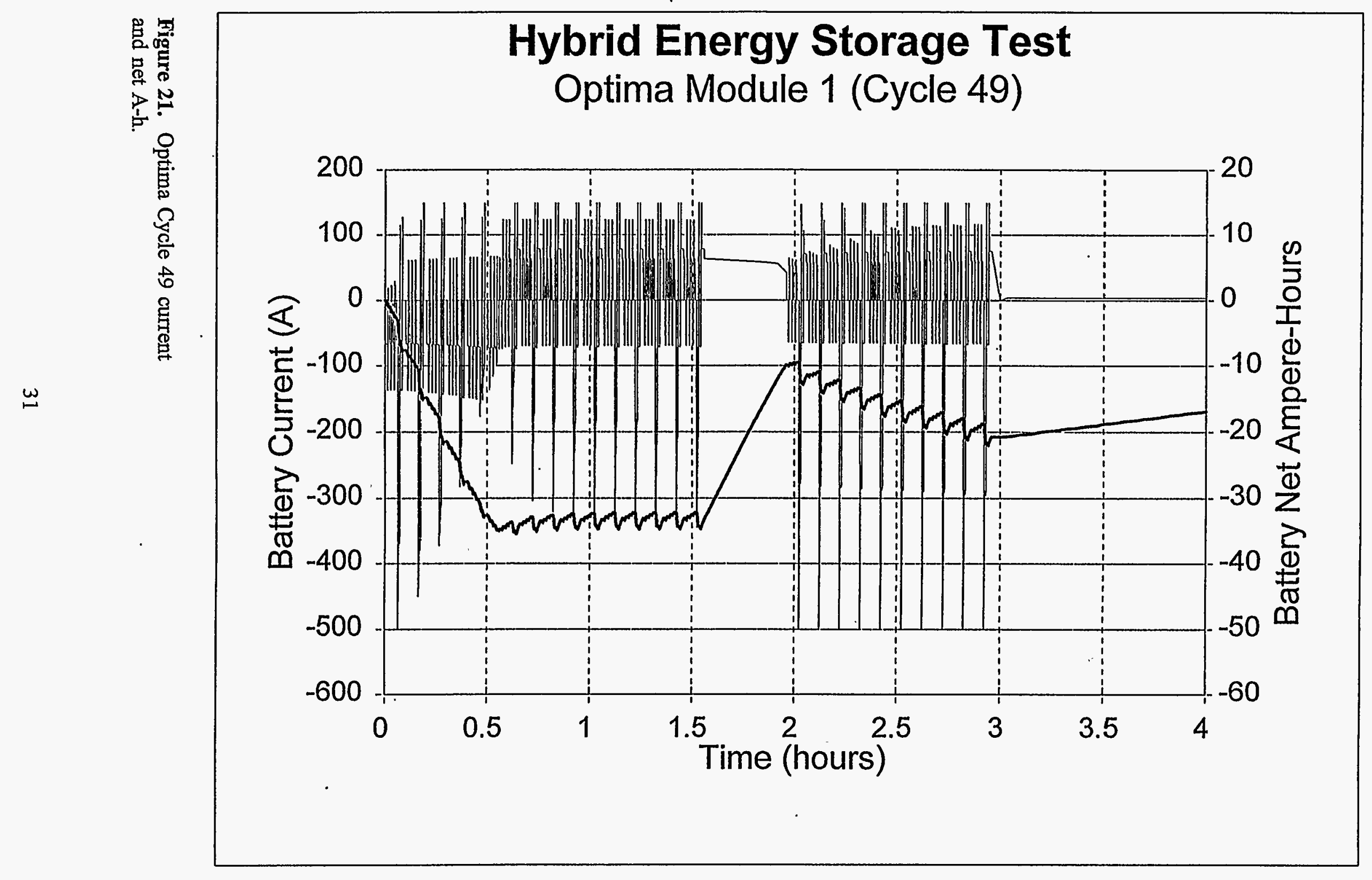




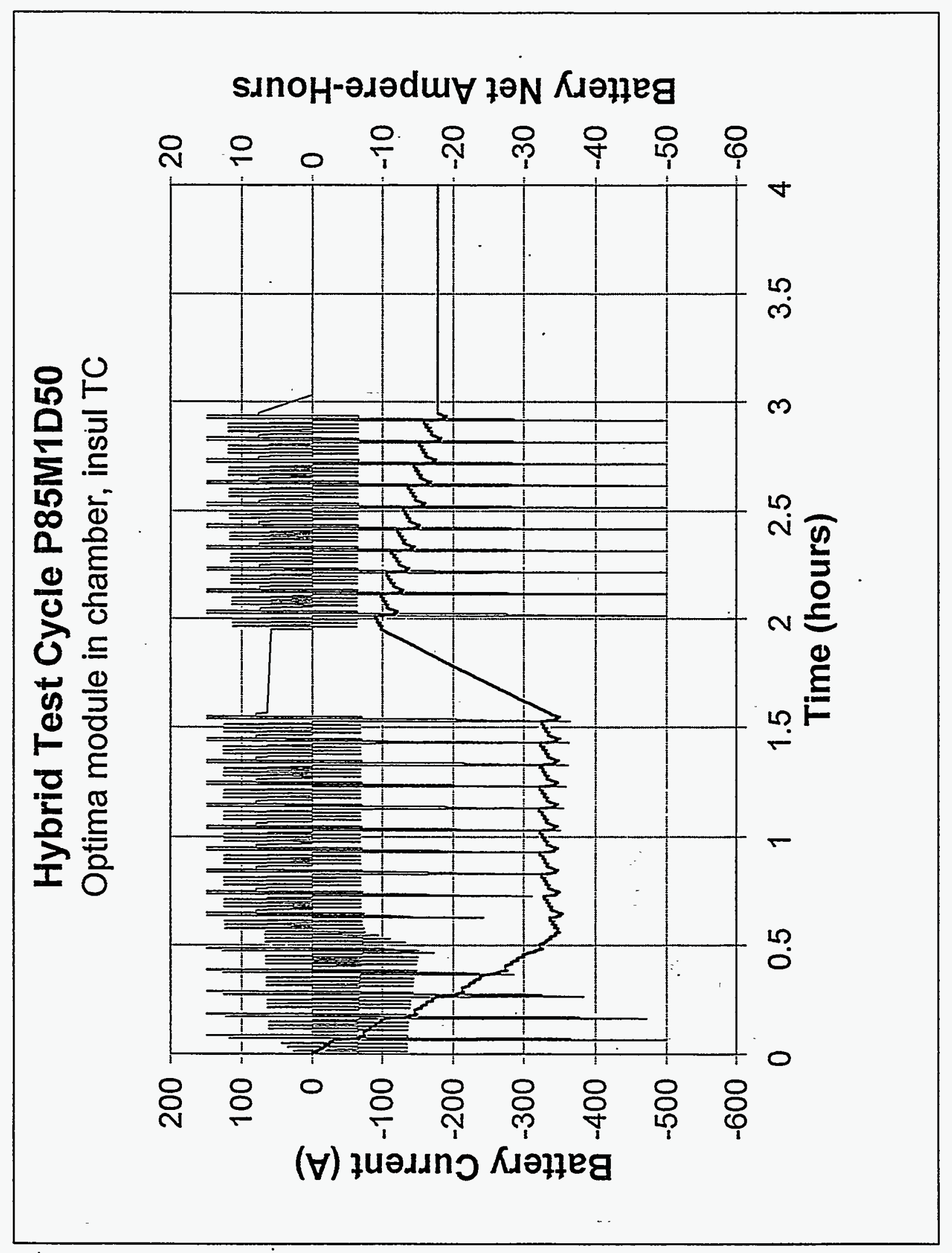

Figure 22. Optima Cycle 50 current and net $A-h$. 


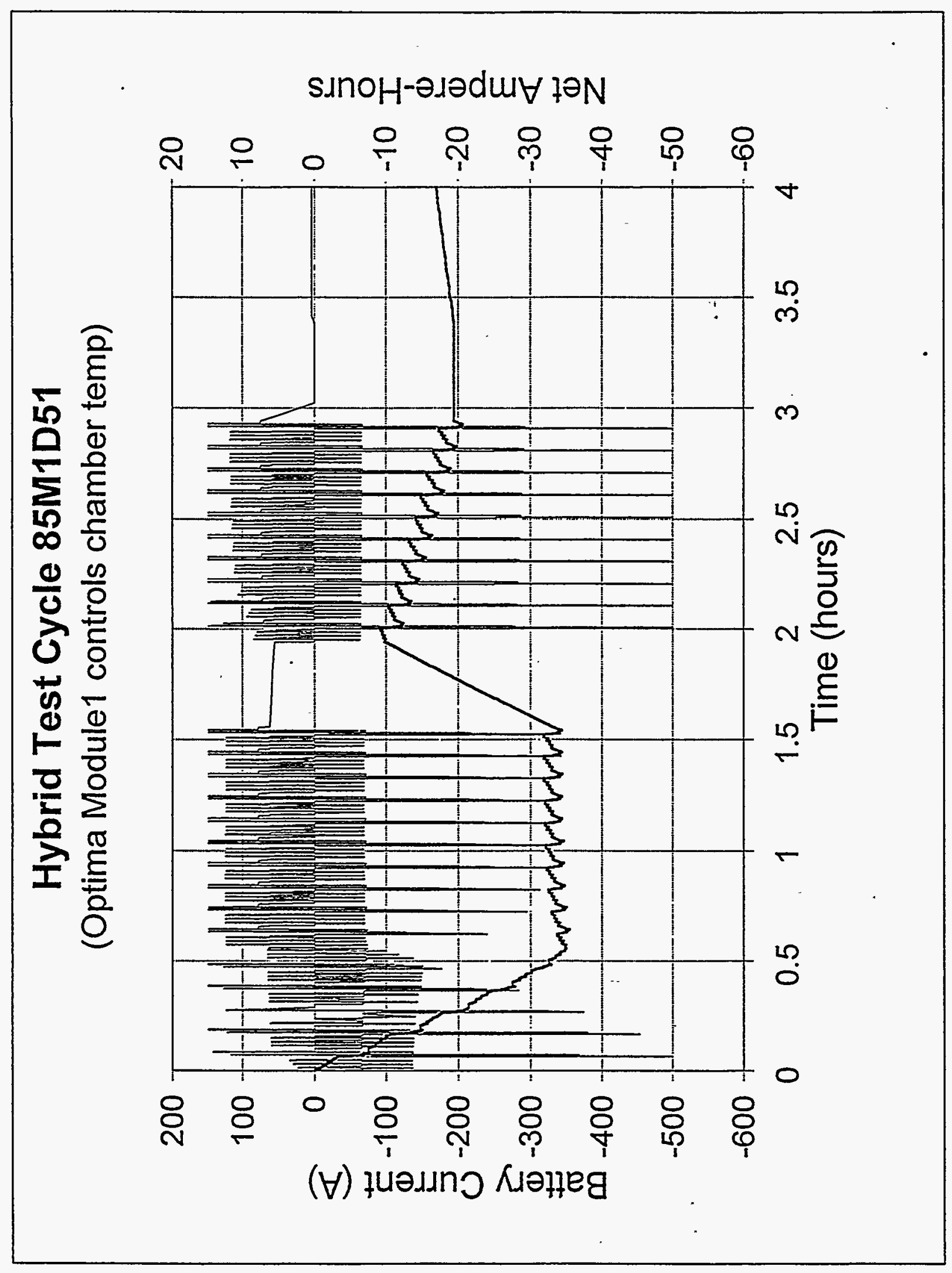

Figure 23. Optima Cycle 51 current and net $A-h$. 


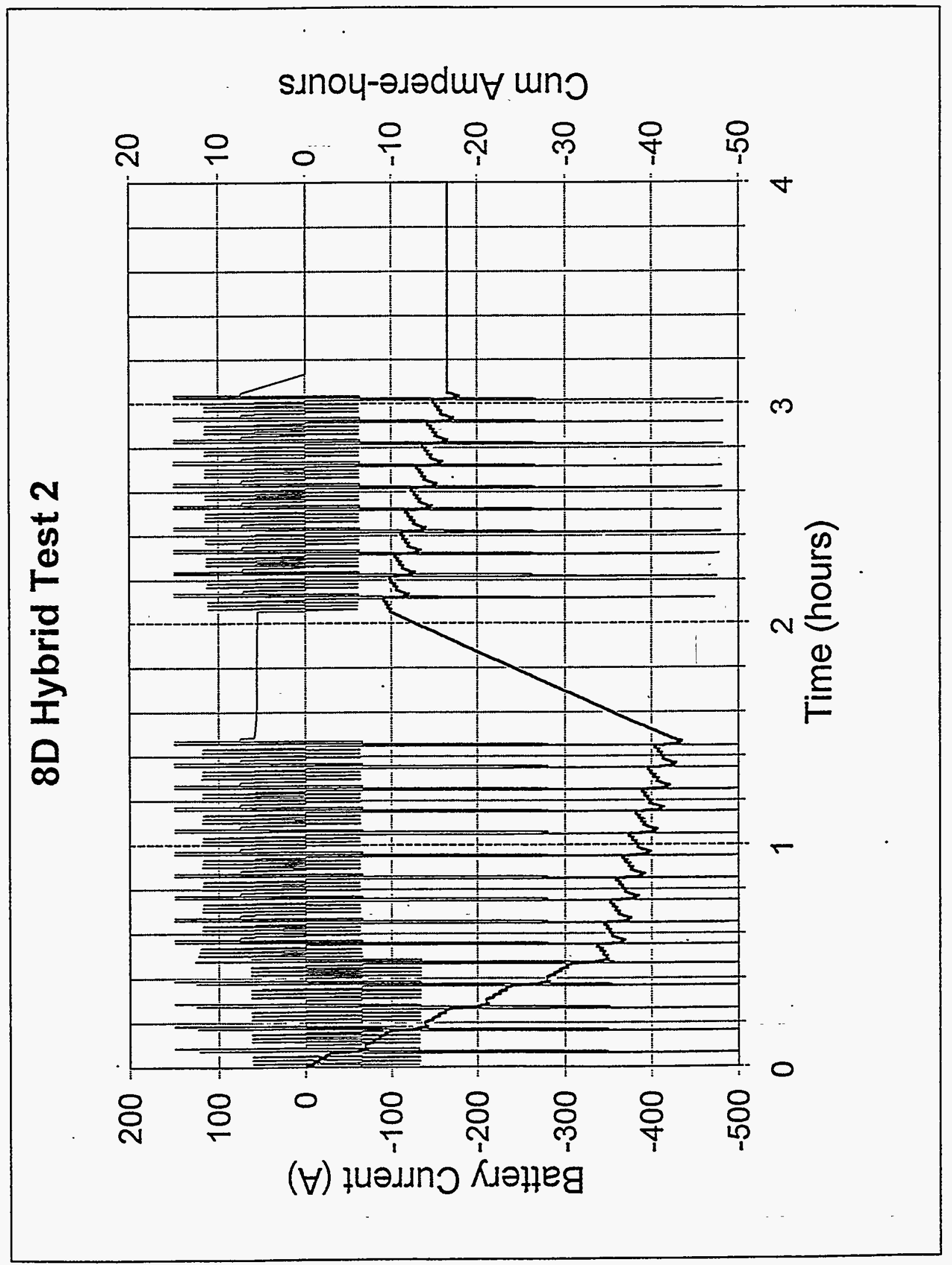

Figure 24. 8D Module current and net A-h. 


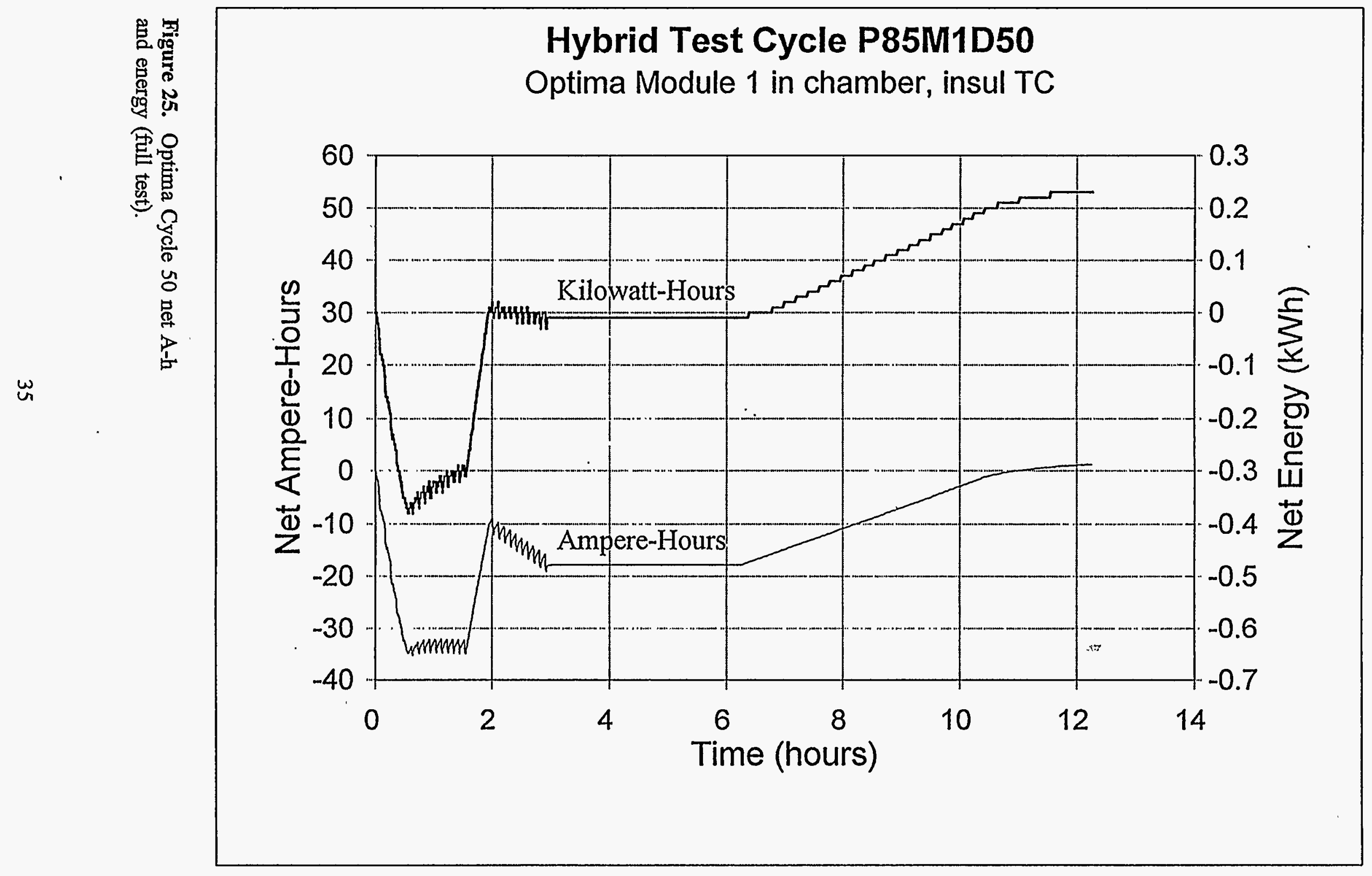




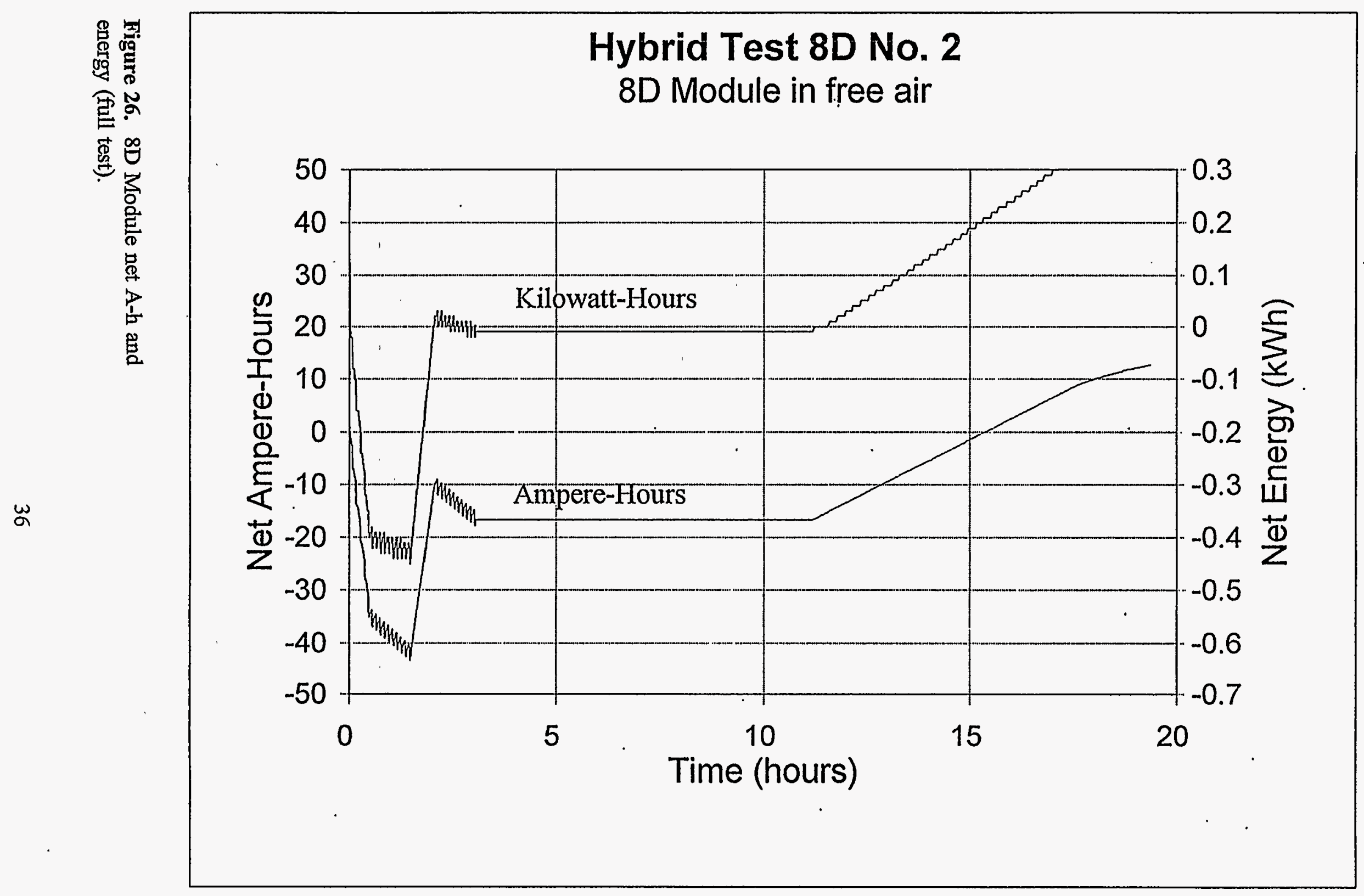




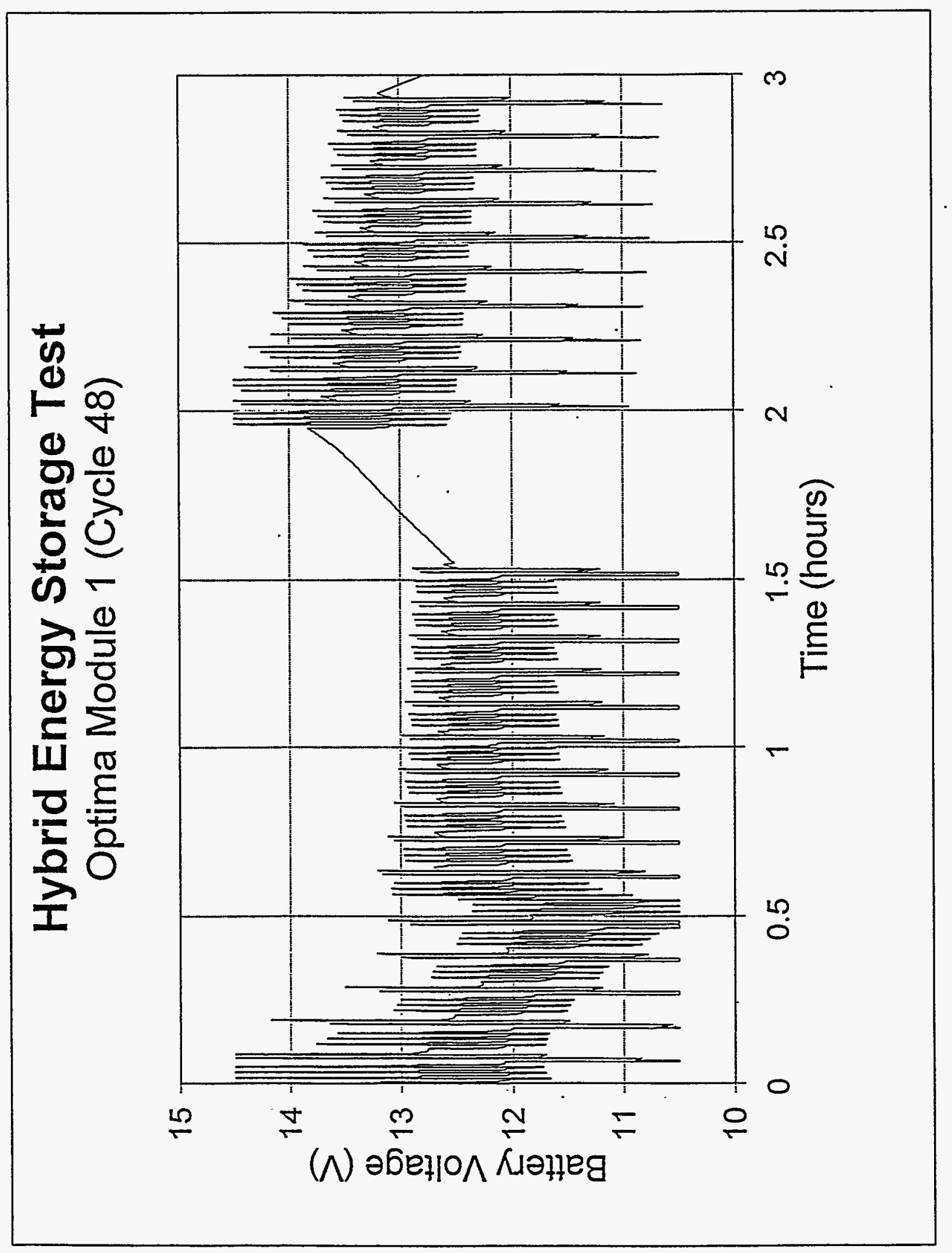

Figure 27. Optima Cycle 48 module voltage. 


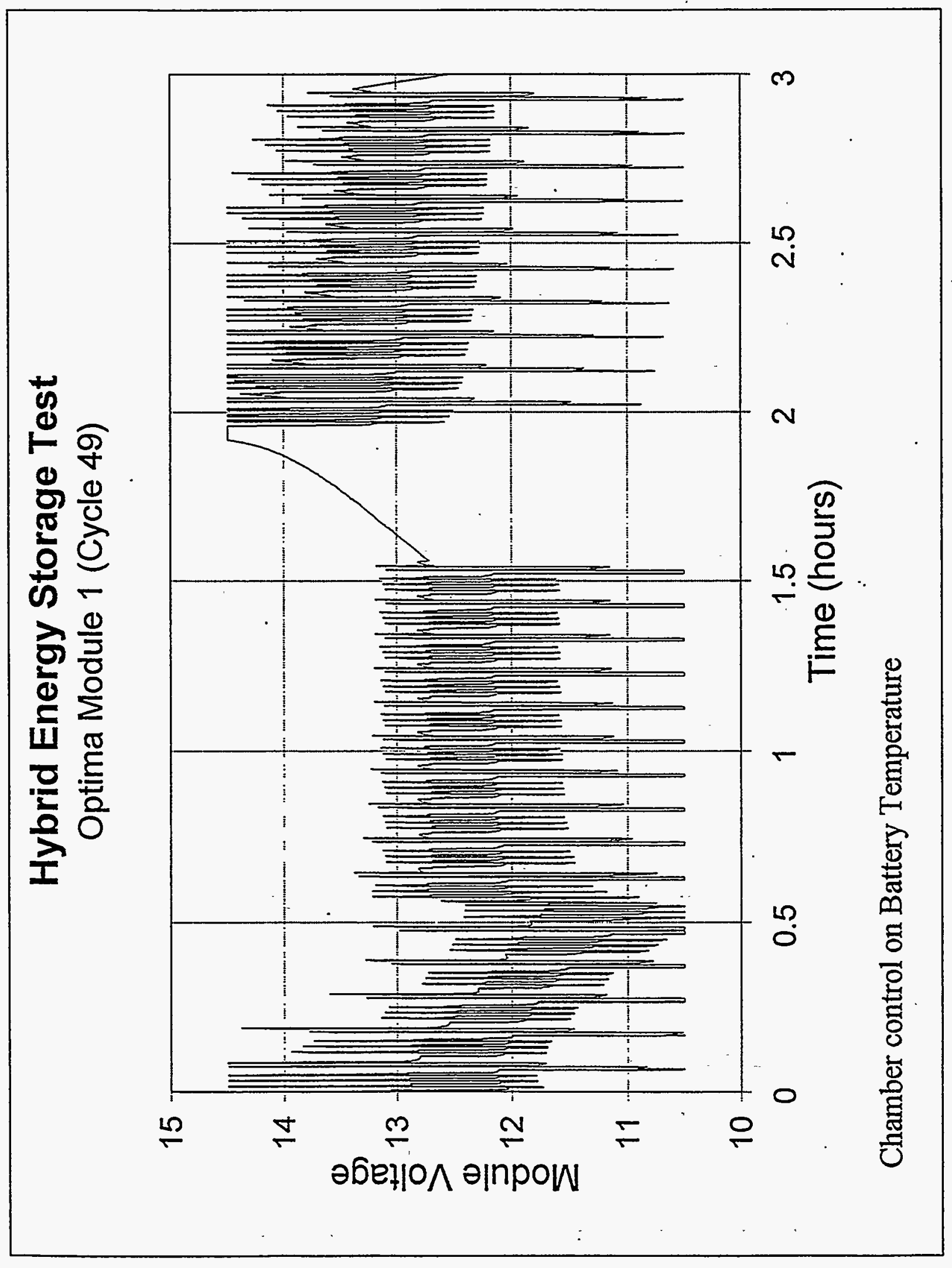

Figure 28. Optima Cycle 49 module voltage. 


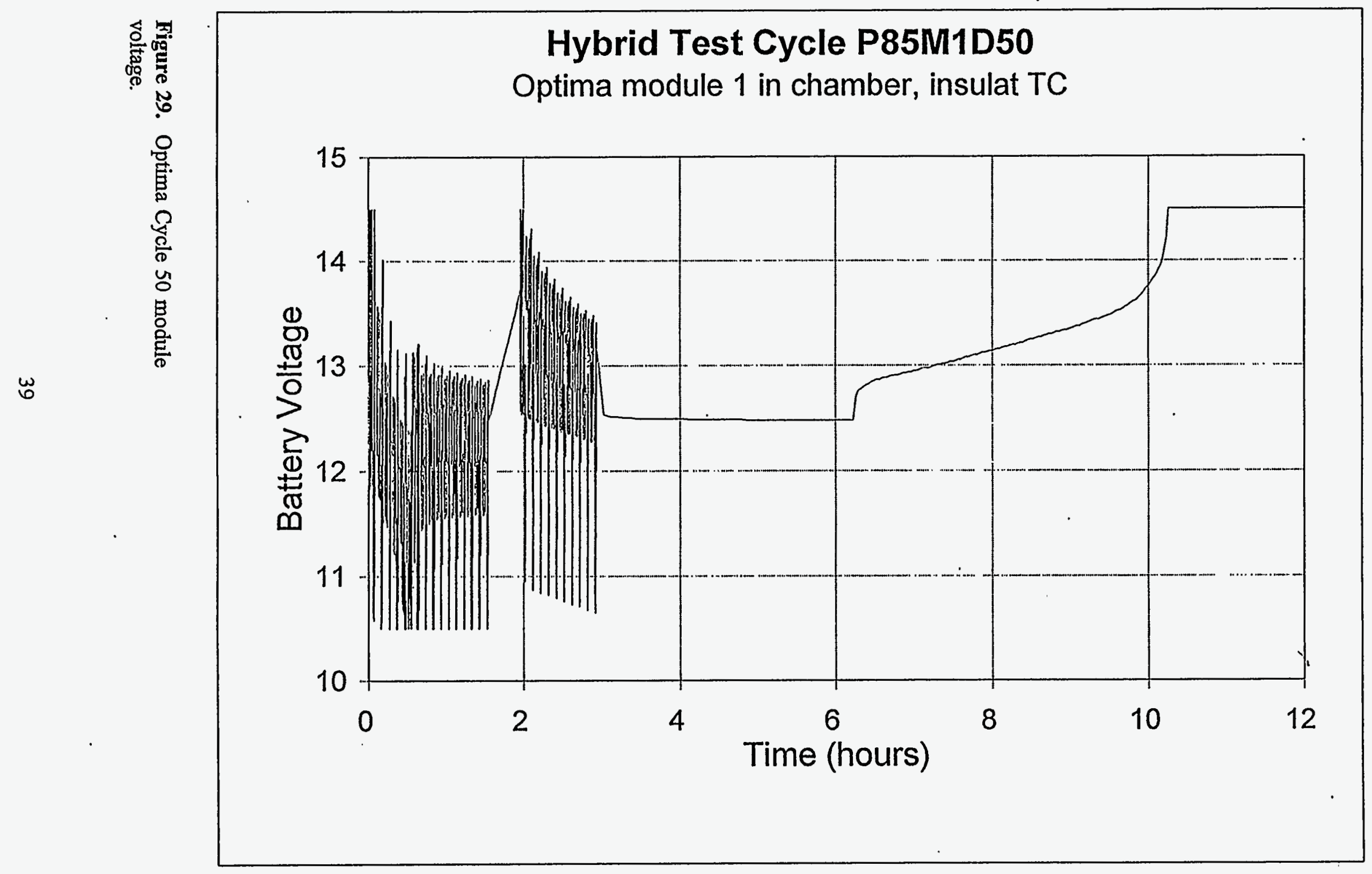




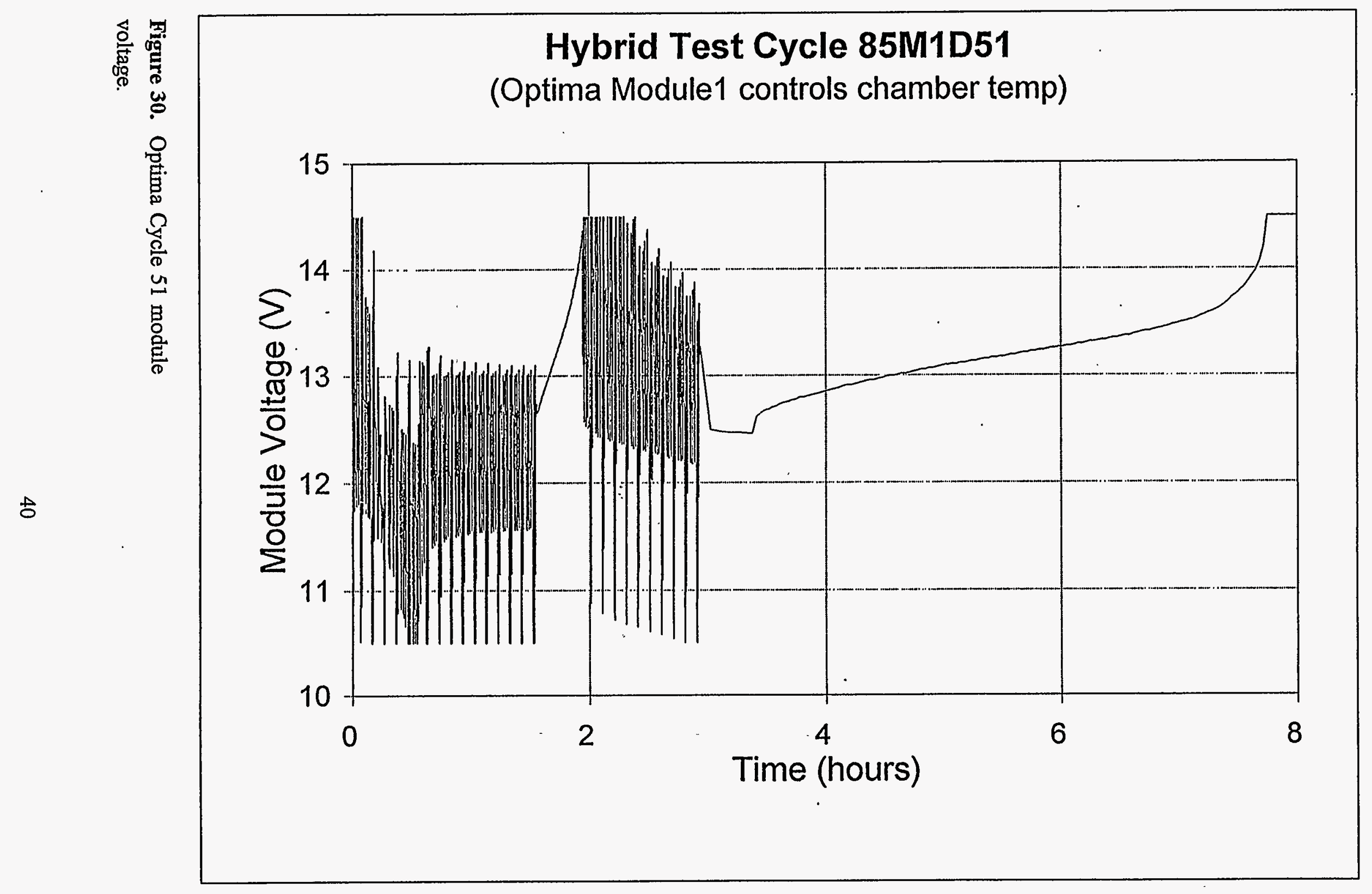




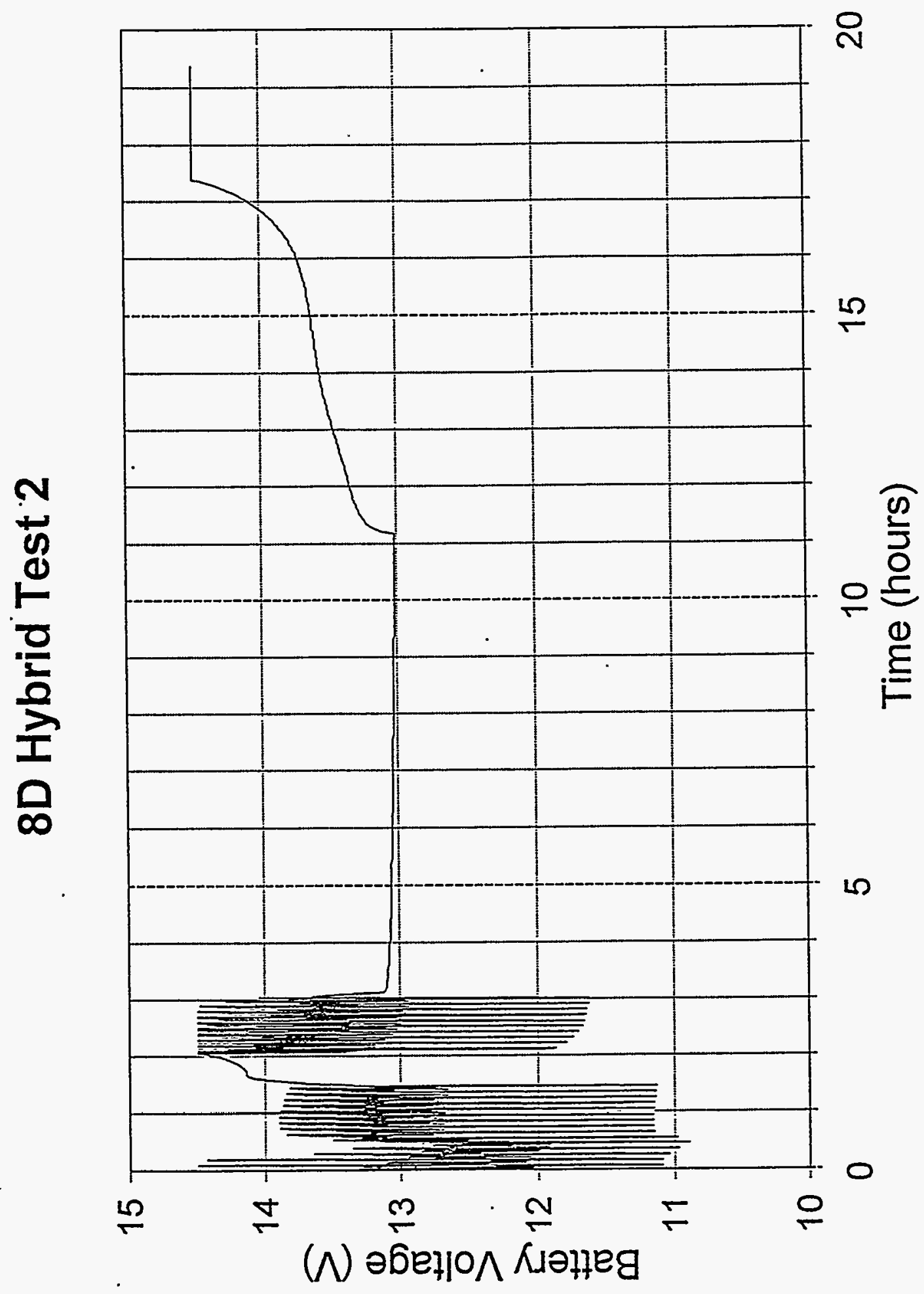

Figure 31. 8D Module voltage. 


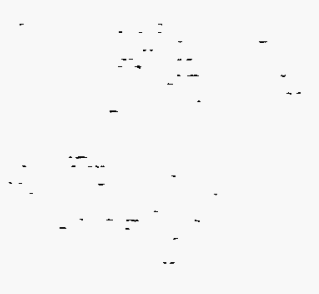

